\title{
Genetic and morphological variation of bee-parasitic Tropilaelaps mites (Acari: Laelapidae): new and re-defined species
}

\author{
Denis L. Anderson • Mathew J. Morgan
}

Received: 21 March 2007 / Accepted: 8 August 2007 / Published online: 9 September 2007

(C) Springer Science+Business Media B.V. 2007

\begin{abstract}
Mites in the genus Tropilaelaps are parasites of social honeybees. Two species, Tropilaelaps clareae and T. koenigerum, have been recorded and their primary hosts are presumed to be the giant honeybees of Asia, Apis dorsata and A. laboriosa. The most common species, $T$. clareae, is also an economically important pest of the introduced Western honeybee (A. mellifera) throughout Asia and is considered an emerging threat to world apiculture. In the studies reported here, genetic (mtDNA CO-I and nuclear ITS1-5.8S-ITS2 gene sequence) and morphological variation and host associations were examined among Tropilaelaps isolates collected from A. dorsata, A. laboriosa and A. mellifera throughout Asia and neighbouring regions. The results clearly indicate that the genus contains at least four species. Tropilaelaps clareae, previously assumed to be ubiquitous in Asia, was found to be two species, and it is here redefined as encompassing haplotypes (mites with distinct mtDNA gene sequences) that parasitise native $A$. dorsata breviligula and introduced $A$. mellifera in the Philippines and also native $A$. $d$. binghami on Sulawesi Island in Indonesia. Tropilaelaps mercedesae n. sp., which until now has been mistaken for T. clareae, encompasses haplotypes that, together with haplotypes of T. koenigerum, parasitise native $A . d$. dorsata in mainland Asia and Indonesia (except Sulawesi Island). It also parasitises introduced A. mellifera in these and surrounding regions and, with another new species, T. thaii n. sp., also parasitises A. laboriosa in mountainous Himalayan regions. Methods are described for identifying each species. These studies help to clarify the emerging threat of Tropilaelaps to world apiculture and will necessitate a revision of quarantine protocols for countries that import and export honeybees.
\end{abstract}

Keywords Tropilaelaps clareae -Tropilaelaps koenigerum - Tropilaelaps mercedesae $\mathrm{n}$. sp. · Tropilaelaps thaii $\mathrm{n}$. sp. · CO-I and ITS1-5.8S-ITS2 gene sequences ·

Genetic variation $\cdot$ Host specificity

D. L. Anderson $(\bowtie)$

CSIRO Entomology, P.O. Box 1700, Canberra, ACT 2601, Australia

e-mail: Denis.Anderson@csiro.au

M. J. Morgan

Evolutionary Biology Group, School of Botany and Zoology, Australian National University,

Canberra, ACT 2601, Australia 


\section{Introduction}

Mites in the genus Tropilaelaps (Acari: Laelapidae) are damaging parasites of the brood of social honeybees (Apis spp.). The best-known species, Tropilaelaps clareae Delfinado and Baker, was first isolated from a colony of the Western honeybee, Apis mellifera Linnaeus, in the Philippines, and from field rats nesting nearby (Delfinado and Baker 1961). Its primary host was subsequently recognized as the 'giant' Asian honeybee, A. dorsata Fabricius (Laigo and Morse 1968) and it has now been reported throughout the entire distribution range of A. dorsata (Matheson 1996), except Sri Lanka, where A. dorsata hosts the only other recognized species of the genus, T. koenigerum Delfinado-Baker and Baker. This enigmatic mite has also been found sympatric with $T$. clareae on A. dorsata in India, Nepal, Thailand and Borneo, (Delfinado-Baker and Baker 1982; Delfinado-Baker et al. 1985; Koeniger et al. 2002; Tangjingjai et al. 2003).

Adults of T. clareae and T. koenigerum are superficially alike in that they are small ( $<1 \mathrm{~mm}$ long), elongated, light brown, fast moving and hold their first pair of legs upright, resembling antennae. However, they are morphologically distinct (Delfinado and Baker 1961; Delfinado-Baker and Baker 1982), their internal transcribed spacer (ITS) genes differ by almost $4 \%$ and their RAPD profiles are quite different (Tangjingjai et al. 2003).

Although A. dorsata is the presumed primary host of T. clareae and T. koenigerum, both mites have also been found feeding and reproducing on brood of the world's largest honeybee, A. laboriosa Smith (Delfinado-Baker et al. 1985), which is found in Himalayan regions above $2000 \mathrm{~m}$ (Sakagami et al. 1980; Otis 1996). They have also been occasionally reported from colonies of the small Asian honeybee, A. cerana Fabricius, and the dwarf Asian honeybee, A. florea Fabricius (Delfinado-Baker 1982; Aggarwal 1988; DelfinadoBaker et al. 1989), although there are no reports of them reproducing on the brood of those bees (Otis and Kralj 2001). Tropilaelaps clareae, but not T. koenigerum, also developed a penchant for A. mellifera when that bee was introduced into Asia by humans. On A. mellifera, $T$. clareae adults feed and reproduce solely on the drone and worker broods (not on adult bees). Initial infestations can rapidly lead to the death of entire bee colonies, and hence the mite is often considered as a more damaging pest of A. mellifera in Asia than the parasitic mite Varroa destructor Anderson and Trueman (Laigo and Morse 1968; Burgett et al. 1983; Tangkanasing et al. 1988; Burgett et al. 1990; Otis and Kralj 2001).

Since switching to A. mellifera, T. clareae has spread beyond the geographical range of its primary honeybee host to Iran, Afghanistan, Kenya, South Korea and the Western Pacific island of New Guinea (Burgett et al. 1983; Matheson 1996; Woyke 1984; Delfinado-Baker and Aggarwal 1987; Kumar et al. 1993; Anderson 1994; Sammataro et al. 2000; Otis and Kralj 2001). In many of these locations the mite has developed into a persistent and damaging pest of $A$. mellifera (Woyke 1984; 1987; 1994) and hence it is widely recognized as an emerging threat to that bee worldwide (OIE 2004).

The studies reported here were aimed at gaining a clearer understanding of the genetic and morphological variation of Tropilaelaps mites and their association with honeybees. Isolates of Tropilaelaps were collected from honeybee hosts throughout Asia and neighbouring regions. Genetic variation among the isolates was determined using mtDNA (CO-I) and nuclear DNA (ITS1-5.8S-ITS2) gene sequences which, in other studies on Acari, have proved useful in differentiating mites at the intra/interspecies and interspecies level respectively (Navajas et al. 1994; 1998; Anderson and Trueman 2000; Navajas and Fenton 2000; Tangjingjai et al. 2003; Walter and Campbell 2003). Morphological studies and observations on mite reproduction helped with the interpretation of molecular data and with determining the associations between mites and their honeybee hosts. 


\section{Methods}

Mite isolates

Adults and other developmental stages of Tropilaelaps were collected alive from inside sealed brood cells of $52 \mathrm{~A}$. dorsata, 1 A. laboriosa and 36 hived A. mellifera colonies in Asia and neighbouring regions (Tables 1, 2 and Fig. 1). The types of brood cells invaded (i.e., worker or drone) and the reproductive state of the invading mites (i.e., reproducing versus non-reproducing) were noted. Collected mites were preserved in $70 \%$ alcohol, transported to the laboratory in Canberra, examined with a dissecting microscope and tentatively identified as $T$. clareae or $T$. koenigerum, based on published morphological descriptions (Delfinado and Baker 1961; Delfinado-Baker and Baker 1982). Adult mites collected from an A. laboriosa colony in a mountainous region of Vietnam (site 53, Table 1) were clearly morphologically different from the two described species. Adult female:male sex ratios in individual samples were then recorded. Following laboratory examinations all mites were placed in fresh alcohol and stored at $-20^{\circ} \mathrm{C}$ until needed for genetic and morphological analyses.

An adult female Tropilaelaps and two white nymphs were also collected from a capped worker cell of an A. cerana colony on 30 January 2003 near Chiang Mai in northern Thailand. These mites were identified during our genetic analyses.

Genetic analyses

Genetic variation between different Tropilaelaps isolates was determined from mitochondrial CO-I and nuclear ITS1-5.8s-ITS2 gene sequences obtained from two adult mites of each isolate. To obtain these sequences, DNA was first extracted and purified from entire mites or their leg tissue using DNeasy® Tissue Kits (Qiagen), as instructed by the manufacturer. A region of the CO-I gene was amplified by polymerase chain reaction (PCR) (Saiki 1990) using an Eppendorf Mastercycler®, a TCF1 forward primer (5'-CTATCCTC AATTATTGAAATAGGAAC-3') and a TCR2 reverse primer (5'-TAGCGGCTGTGAA ATAGGCTCG-3') as described by Anderson et al. (1998), except that each PCR consisted of pre-denaturation at $94^{\circ} \mathrm{C}$ for $1 \mathrm{~min}$, followed by 35 cycles of denaturation at $94^{\circ} \mathrm{C}$ for $30 \mathrm{~s}$, a $30 \mathrm{~s}$ annealing at $47^{\circ} \mathrm{C}$, a $30 \mathrm{~s}$ extension at $72^{\circ} \mathrm{C}$ and a final extension at $72^{\circ} \mathrm{C}$ for $2 \mathrm{~min}$. The entire ITS1-5.8S-ITS2 gene region was similarly amplified using an ITS5 primer (5'-GGAAGTAAAAGTCGTAACAAGG-3') and an ITS4 primer (5' ${ }^{\prime}$-TCCTCCGC TTATTGATATGC-3') (White et al. 1990) with PCR thermo-cycles of 5 min pre-denaturation at $94^{\circ} \mathrm{C}, 35$ cycles of denaturation at $94^{\circ} \mathrm{C}$ for $1 \mathrm{~min}, 1 \mathrm{~min}$ annealing at $52^{\circ} \mathrm{C}$, a 2 min extension at $72^{\circ} \mathrm{C}$ and a final extension at $72^{\circ} \mathrm{C}$ for $5 \mathrm{~min}$.

Amplified DNA was sequenced using a CEQ ${ }^{\mathrm{TM}} 8000$ Genetic Analysis System (Beckman Coulter) in combination with the specific PCR primers and $\mathrm{CEQ}^{\mathrm{TM}}$ Dye Terminator Cycle Sequencing with Quick Start Kits (Beckman Coulter), as per the manufacturer's instructions. Both DNA strands were sequenced at least four times to confirm the accuracy of the sequence.

DNA sequences were compared with those in the GenBank database using BLAST and BioManager programs via the networked facilities of the Australian National Genomic Information Services. Sequences were aligned separately by eye and analysed using PAUP*4.0d64 (Swofford 1998). Alignment gaps were only observed among the ITS1-5.8S-ITS2 sequences and these were coded as new characters (Simmons and Ochoterena 2000). Alignments were tested for substitution saturation by plotting pairwise 
Table 1 Details of Tropilaelaps isolates collected from Apis dorsata colonies (sites 1-52) and an A. laboriosa colony (site 53, italics text) and of the identity of mites in each isolate

\begin{tabular}{|c|c|c|}
\hline Site $^{\mathrm{a}}$ & $\begin{array}{l}\text { Location and date of collection: } \\
\text { COUNTRY (Island) } \\
\text { [Province, District or Locality] } \\
\{\text { Month/Year Collected }\}\end{array}$ & $\begin{array}{l}\text { Identity of mites: (MtDNA } \\
\text { Haplotype/GenBank } \\
\text { Accession No./Species) }\end{array}$ \\
\hline 1 & CHINA[Yunnan] $\{6 / 2004\}$ & $\begin{array}{l}\text { (China 1/EF025429/Tm)+ } \\
\quad \text { (China 2/EF025430/Tm) }\end{array}$ \\
\hline 2 & CHINA[Yunnan] $\{6 / 2004\}$ & $\begin{array}{l}\text { (China 3/EF025431/Tm)+ } \\
\quad \text { (China 4/EF025432/Tm) }\end{array}$ \\
\hline 3 & INDIA[Bangalore $]\{5 / 2004\}$ & (India 1/EF025433/Tm) \\
\hline 4 & INDONESIA(Bali)[Asahduren] $\{8 / 2002\}$ & (Java 1/EF025434/Tm) \\
\hline 5 & $\begin{array}{l}\text { INDONESIA(Belitung) } \\
\quad[\text { Tanjung Rusa]\{3/2002\} }\end{array}$ & $\begin{array}{l}\text { (Belitung 1/EF025423/Tm)+ } \\
\quad \text { (Belitung 2/EF025424/Tm) }\end{array}$ \\
\hline 6 & $\begin{array}{l}\text { INDONESIA(Borneo) } \\
\quad[\text { Bulungan Regency] }\{3 / 2004\}\end{array}$ & $\begin{array}{c}\text { (Borneo 2/EF025426/Tm) }+ \\
(\text { Borneo 3/EF025427/Tm)+ } \\
(\text { TkBorneo 1/EF025449/Tk) }\end{array}$ \\
\hline 7 & $\begin{array}{l}\text { INDONESIA(Borneo) } \\
\quad[\text { Bulungan Regency] }\{3 / 2004\}\end{array}$ & $\begin{array}{l}\text { (Borneo 1/EF025425/Tm)+ } \\
\quad(\text { Borneo 4/EF025428/Tm)+ } \\
\quad(\text { TkBorneo 1/Tk) }\end{array}$ \\
\hline 8 & INDONESIA(Java)[Sukabumi] $\{4 / 2002\}$ & (Java 2/EF025435/Tm) \\
\hline 9 & INDONESIA(Java)[West Java] $\{11 / 2000\}$ & (Java $1 /$ Tm) \\
\hline 10 & INDONESIA(Lombok)[Sambelia] $\{7 / 2003\}$ & $\begin{array}{l}\text { (Lombok-Sumbawa/EF025436/Tm)+ } \\
\text { (TkLombok 1/EF025450/Tk) }\end{array}$ \\
\hline 11 & INDONESIA(Lombok)[Sambelia] $\{7 / 2003\}$ & (Lombok-Sumbawa/Tm)+(TkLombok 1/Tk) \\
\hline 12 & INDONESIA(Lombok)[Sambelia] $\{7 / 2003\}$ & (Lombok-Sumbawa/Tm)+(TkLombok 1/Tk) \\
\hline 13 & INDONESIA(Sulawesi)[Kulaka] $\{11 / 2003\}$ & $\begin{array}{l}\text { (Sulawesi 2/EF025467/Tc)+ } \\
\quad \text { (Sulawesi 3/EF025468/Tc) }\end{array}$ \\
\hline 14 & INDONESIA(Sulawesi)[Palu] $\{4 / 2000\}$ & (Sulawesi 1/EF025466/Tc) \\
\hline 15 & INDONESIA(Sumatra)[Medan] $\{4 / 2000\}$ & (Sumatra 1/EF025443/Tm) \\
\hline 16 & INDONESIA(Sumatra)[Ria] $\{3 / 2002\}$ & $\begin{array}{l}\text { (Sumatra 1/Tm })+(\text { Belitung 1/Tm })+ \\
\quad(\text { TkSumatra 1/EF025451/Tk })\end{array}$ \\
\hline 17 & $\begin{array}{r}\text { INDONESIA(Sumbawa) } \\
{[\text { Lape Lopor }]\{7 / 2003\}}\end{array}$ & (Lombok-Sumbawa/Tm)+(TkLombok 1/Tk) \\
\hline 18 & $\begin{array}{l}\text { INDONESIA(Sumbawa) } \\
{[\text { Lape Lopor }]\{7 / 2003\}}\end{array}$ & (Lombok-Sumbawa/Tm) \\
\hline 19 & LAOS[Vang Vieng] $\{4 / 2000\}$ & (Mainland Asia/EF025437/Tm) \\
\hline 20 & MALAYSIA(Borneo) $[$ Tenom $]\{2 / 2000\}$ & (Borneo $1 / \mathrm{Tm})$ \\
\hline 21 & MALAYSIA[Lake Pedu] $\{3 / 1995\}$ & (Malaysia 1/EF025438/Tm) \\
\hline 22 & MALAYSIA[Lake Pedu] $\{3 / 1995\}$ & (Malaysia 1/Tm)+(Malaysia 2/EF025439/Tm) \\
\hline 23 & PHILIPPINES(Bohol)[Bilar] $\{2 / 2003\}$ & (Bohol 1/EF025453/Tc) \\
\hline 24 & PHILIPPINES(Bohol)[Bilar] $\{2 / 2003\}$ & (Bohol 1/Tc) \\
\hline 25 & PHILIPPINES(Bohol)[Carmen] $\{2 / 2003\}$ & (Bohol 1/Tc) \\
\hline 26 & PHILIPPINES(Bohol)[Loboc] $\{2 / 2003\}$ & (Bohol 1/Tc) \\
\hline 27 & $\begin{array}{l}\text { PHILIPPINES(Cebu) } \\
\quad[\text { Buanoy District] }\{4 / 2004\}\end{array}$ & (Cebu 1/EF025454/Tc)+(Bohol 1/Tc) \\
\hline 28 & PHILIPPINES(Leyte)[Maasin City] $6 / 2003\}$ & (Leyte 2/EF025456/Tc) \\
\hline 29 & PHILIPPINES(Leyte)[Maasin City] $\{6 / 2003\}$ & (Leyte 1/EF025455/Tc) \\
\hline 30 & PHILIPPINES(Luzon)[Albay] $\{1 / 2003\}$ & (Luzon 1/EF025457/Tc) \\
\hline 31 & PHILIPPINES(Luzon)[Albay]\{1/2003\} & (Luzon $1 / \mathrm{Tc})$ \\
\hline 32 & PHILIPPINES(Luzon)[La Union] $\{2 / 2003\}$ & $\begin{array}{l}\text { (Luzon 3/EF025459/Tc)+ } \\
\quad(\text { Luzon 4/EF025460/Tc) }\end{array}$ \\
\hline 33 & PHILIPPINES(Luzon)[La Union] $\{3 / 2002\}$ & (Luzon $1 / \mathrm{Tc})$ \\
\hline 34 & PHILIPPINES(Luzon)[La Union] $\{3 / 2004\}$ & $\begin{array}{l}\text { (Luzon 5/EF025461/Tc)+ } \\
\quad(\text { Luzon 6/EF025462/Tc) }\end{array}$ \\
\hline 35 & PHILIPPINES(Luzon)[Laguna] $\{1 / 2002\}$ & (Luzon 2/EF025458/Tc) \\
\hline 36 & PHILIPPINES(Luzon)[Laguna] $\{3 / 2004\}$ & (Luzon $1 / \mathrm{Tc})$ \\
\hline
\end{tabular}


Table 1 continued

\begin{tabular}{|c|c|c|}
\hline Site $^{\mathrm{a}}$ & $\begin{array}{l}\text { Location and date of collection: } \\
\text { COUNTRY (Island) } \\
\text { [Province, District or Locality] } \\
\{\text { Month/Year Collected }\}\end{array}$ & $\begin{array}{l}\text { Identity of mites: (MtDNA } \\
\text { Haplotype/GenBank } \\
\text { Accession No./Species) }\end{array}$ \\
\hline 37 & PHILIPPINES(Mindanao)[Bukidnon] $\{9 / 2002\}$ & (Mindanao 1/EF025463/Tc) \\
\hline 38 & PHILIPPINES(Mindoro)[Sablyan] $\{2 / 2004\}$ & (Mindoro 1/EF025464/Tc) \\
\hline 39 & PHILIPPINES(Palawan)[Quezon] $\{3 / 2002\}$ & (Palawan 1/EF025440/Tm) \\
\hline 40 & PHILIPPINES(Siargao)[Del Carmen] $\{5 / 2004\}$ & (Siargao 1/EF025465/Tc) \\
\hline 41 & SRI LANKA[Uva] $\{7 / 2004\}$ & (Sri Lanka 1/EF025441/Tm) \\
\hline 42 & SRI LANKA[Uva] $\{7 / 2004\}$ & $\begin{array}{l}\text { (Sri Lanka 1/Tm)+ } \\
\quad(\text { Sri Lanka 2/EF025442/Tm) }\end{array}$ \\
\hline 43 & THAILAND[Lam Pang] $\{8 / 2004\}$ & (Mainland Asia/Tm) \\
\hline 44 & THAILAND[Lam Pang] $\{8 / 2004\}$ & (Thailand 1/EF025445/Tm) \\
\hline 45 & THAILAND[Lam Pang] $\{8 / 2004\}$ & (Mainland Asia/Tm) \\
\hline $46^{\mathrm{c}}$ & THAILAND[Mae Hong Sorn] $\{7 / 2004\}$ & (Mainland Asia/Tm) \\
\hline 47 & THAILAND[Unknown] $\{3 / 2002\}$ & (Thailand $1 / \mathrm{Tm}$ ) \\
\hline 48 & THAILAND[Unknown] $\{3 / 2002\}$ & (Thailand 2/EF025446/Tm) \\
\hline 49 & VIETNAM[Camau] $\{8 / 2004\}$ & $\begin{array}{l}\text { (Vietnam 1/EF025447/Tm)+ } \\
\text { (Mainland Asia/Tm) }\end{array}$ \\
\hline 50 & VIETNAM[Camau] $\{8 / 2004\}$ & $\begin{array}{l}\text { (Vietnam 2/EF025448/Tm)+ } \\
\text { (Mainland Asia/Tm) }\end{array}$ \\
\hline 51 & VIETNAM[Camau] $\{8 / 2004\}$ & (Mainland Asia/Tm) \\
\hline 52 & VIETNAM[Camau] $\{8 / 2004\}$ & (Mainland Asia/Tm) \\
\hline 53 & VIETNAM[Sonla] $\{7 / 2004\}$ & $\begin{array}{l}\text { (Thailand 1/Tm)+ } \\
\text { (TtVietnam 1/EF025452/Tt) }\end{array}$ \\
\hline
\end{tabular}

\footnotetext{
a Sites correspond with locations in Fig. 1

b Mites were named as described in Results. GenBank accession numbers are for partial CO-I sequences and are only given once. Species: $\mathrm{Tm}=T$. mercedesae, $\mathrm{Tc}=T$. clareae, $\mathrm{Tk}=T$. koenigerum and $\mathrm{Tt}=T$. thaii

c A single female T. koenigerum was collected from this site, but its haplotype was not determined
}

transition:transversion ratios against uncorrected genetic distance. Hierarchical signal tests (PTP tests) were performed on CO-I and ITS1-5.8S-ITS2 alignments prior to phylogenetic tree estimation (Archie 1989).

Phylogenetic analyses using PAUP*4.0d64 were performed under three optimality criteria: maximum parsimony, maximum likelihood and neighbour-joining. The maximum parsimony analyses were performed using equal weighing of all changes (unweighted parsimony). Additional analyses were performed with transversions given twice the weight of transitions (transversion-weighted parsimony) and with third codon positions given half the weight of first and second positions. Heuristic searches were performed using 10 random-stepwise addition replicates with tree-bisection-reconnection branch swapping. Statistical support for relationships was assessed by the nonparametric bootstrap procedure using 1000 replicates, with 70\% support considered well-supported (Hillis and Bull 1993; Efron et al. 1996). The maximum likelihood analyses were performed using a GTR $+\mathrm{I}+\mathrm{G}$ model of sequence evolution obtained using ModelTest 3.06 (Posada and Grandall 1998). Finally, neighbour-joining analyses were performed using distance matrices based on both $p$ distances and log-determinant (LogDet) distances (Steel 1994; Lockhart et al. 1994). LogDet distances were used to compensate for base composition bias between the ingroup and outgroup sequences.

Species-specific markers were developed using restriction enzyme sites located within the CO-I and ITS1-5.8S-ITS2 gene sequences. Enzymes corresponding to these sites were used to digest PCR amplified DNA and the products visualized as bands in $2 \%$ agarose gels 
Table 2 Details of the Tropilaelaps isolates collected from Apis mellifera colonies and the identity of mites in each isolate

\begin{tabular}{|c|c|c|}
\hline Site $^{\mathrm{a}}$ & $\begin{array}{l}\text { Location and date of collection: COUNTRY (Island) } \\
{[\text { Province, District or Locality }]\{\text { Month/Year Collected }\}}\end{array}$ & $\begin{array}{l}\text { Identity of mites: } \\
\text { (MtDNA Haplotype/Species) }^{\mathrm{b}}\end{array}$ \\
\hline A & BURMA[Shan State $]\{11 / 2003\}$ & (Thailand 1/Tm) \\
\hline B & CHINA[Guizhou $]\{9 / 2001\}$ & (Mainland Asia/Tm) \\
\hline $\mathrm{C}$ & CHINA[Zejiang] $\{11 / 2001\}$ & (Mainland Asia/Tm) \\
\hline $\mathrm{D}$ & INDIA[Bangalore] $\{3 / 2002\}$ & (Mainland Asia/Tm) \\
\hline $\mathrm{E}$ & INDIA[Bangalore] $\{3 / 2002\}$ & (Mainland Asia/Tm) \\
\hline $\mathrm{F}$ & INDONESIA(Java)[Batu]\{10/1997\} & (Java 2/Tm) \\
\hline $\mathrm{G}$ & INDONESIA(Java)[Bogor] $\{10 / 2003\}$ & (Java 2/Tm) \\
\hline $\mathrm{H}$ & INDONESIA(Java)[Lido] $\{4 / 2002\}$ & (Java 2/Tm) \\
\hline I & INDONESIA(Java)[Sukabumi] $\{3 / 1993\}$ & (Java 2/Tm) \\
\hline $\mathrm{J}$ & INDONESIA(Java)[Sukabumi] $\{3 / 1999\}$ & Java 1/Tm) \\
\hline $\mathrm{K}$ & INDONESIA[Papua, Koya Timor] $\{2 / 2003\}$ & (Java 1/Tm) \\
\hline $\mathrm{L}$ & INDONESIA[Papua, Koya Timor] $\{8 / 2002\}$ & (Java 1/Tm) \\
\hline M & INDONESIA[Papua, Nabiri] $\{11 / 1995\}$ & (Java 1/Tm) \\
\hline $\mathrm{N}$ & INDONESIA[Papua, Wamena]\{4/1995\} & (Java 1/Tm) \\
\hline $\mathrm{O}$ & INDONESIA[Papua, Wamena] $\{11 / 1996\}$ & (Java 1/Tm) \\
\hline $\mathrm{P}$ & PAPUA NEW GUINEA[Vanimo] $\{4 / 1995\}$ & (Java 1/Tm) \\
\hline Q & PAPUA NEW GUINEA[Vanimo] $\{9 / 1995\}$ & (Java 1/Tm) \\
\hline $\mathrm{R}$ & PHILIPPINES(Luzon)[Cavite] $\{3 / 2001\}$ & (Luzon $1 / \mathrm{Tc}$ ) \\
\hline $\mathrm{S}$ & PHILIPPINES(Luzon)[Albay] $\{2 / 2003\}$ & (Luzon $1 / \mathrm{Tc}$ ) \\
\hline $\mathrm{T}$ & PHILIPPINES(Luzon)[Camarines Sur] $\{9 / 2002\}$ & (Luzon $1 / \mathrm{Tc}$ ) \\
\hline $\mathrm{U}$ & PHILIPPINES(Luzon)[Ilocos Norte] $\{3 / 2002\}$ & (Luzon 6/Tc) \\
\hline V & PHILIPPINES(Luzon)[La Union] $[6 / 2004\}$ & (Luzon $1 / \mathrm{Tc}$ ) \\
\hline $\mathrm{W}$ & PHILIPPINES(Luzon)[La Union] $\{9 / 2001\}$ & (Luzon $1 / \mathrm{Tc}$ ) \\
\hline $\mathrm{X}$ & PHILIPPINES(Luzon)[La Union] $\{9 / 2001\}$ & (Luzon $1 / \mathrm{Tc}$ ) \\
\hline $\mathrm{Y}$ & PHILIPPINES(Luzon)[Laguna] $\{3 / 2001\}$ & (Luzon $2 / \mathrm{Tc}$ ) \\
\hline $\mathrm{Z}$ & PHILIPPINES(Mindanao)[Davao] $\{4 / 1998\}$ & (Mindanao $1 / \mathrm{Tc}$ ) \\
\hline Aa & SOUTH KOREA[Pungup] $\{3 / 1995\}$ & (Mainland Asia/Tm) \\
\hline $\mathrm{Bb}$ & THAILAND[Chiang Mia] $\{4 / 2002\}$ & (Thailand 1/Tm) \\
\hline $\mathrm{Cc}$ & THAILAND[Bangkok] $\{1 / 2003\}$ & (Mainland Asia/Tm) \\
\hline Dd & THAILAND[Bangkok] 8 8/1994\} & (Thailand 1/Tm) \\
\hline $\mathrm{Ee}$ & THAILAND[Chiang Mia] $\{1 / 2003\}$ & (Thailand 2/Tm) \\
\hline $\mathrm{Ff}$ & THAILAND[Chiang Mia] $\{1 / 2003\}$ & (Thailand 2/Tm) \\
\hline $\mathrm{Gg}$ & THAILAND[Chiang Mia] $\{7 / 2004\}$ & (Thailand 2/Tm) \\
\hline $\mathrm{Hh}$ & THAILAND[Chiang Mia] $\{7 / 2004\}$ & (Thailand 1/Tm) \\
\hline Ii & VIETNAM[Dong Nai] $]$ 10/1996\} & (Vietnam 2/Tm) \\
\hline $\mathrm{Jj}$ & VIETNAM[Hanoi] $\{8 / 2004\}$ & (Mainland Asia/Tm) \\
\hline
\end{tabular}

\footnotetext{
a Sites correspond with locations in Fig. 1

b Species: As in Table 1
}

(Anderson and Fuchs 1998). These markers were subsequently used to confirm the identity of at least $10 \%$ of the adult mites of each isolate.

\section{Morphological analyses}

Light microscopy (LM) and scanning electron microscopy (SEM) were used to examine physical characteristics of adult male and female Tropilaelaps that our DNA analyses had shown were genetically distinct. Characters examined included body size, the structure of dorsal shields, the shape, structure and chaetotaxy of sternal, epigynial and anal plates, the peritremes, tritosterna and hypostomes, and the number, arrangement and morphology of body setae, but not leg setae. Body lengths were measured along the midlines of dorsal 


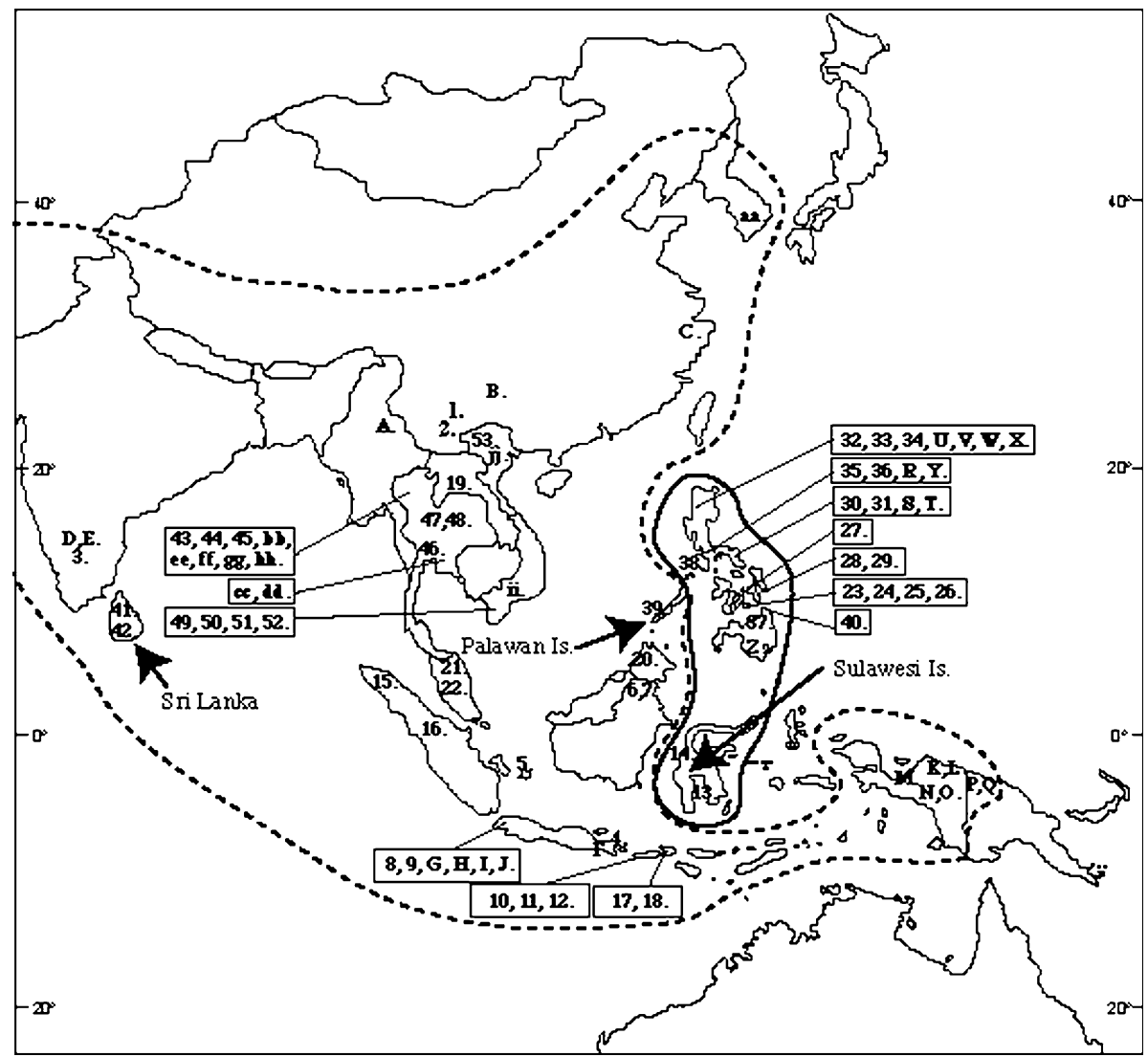

Fig. 1 Sites where Tropilaelaps mites were collected from A. dorsata, A. laboriosa and A. mellifera. Numbers and letters correspond to sites given in Tables 1 and 2, respectively. Broken line indicates the approximate distribution of Clades 1 and 3 (T. mercedesae and T. koenigerum respectively) and unbroken line that of taxa of Clade 2 (T. clareae). Mites from Sri Lanka and Palawan Island (arrowed) were sub-taxa of Clade 1 and, from Sulawesi Island (also arrowed), sub-taxa of Clade 2

shields, and body widths were measured across the broadest region of these shields. For LM, mites were first cleared in Nesbitt's solution and slide mounted in Hoyer's medium (Krantz 1978). For SEM, mites were first critical point dried, mounted in colloidal silver on metal stubs, coated with gold, and examined at $15 \mathrm{Kv}$ in a Joel 6400 scanning electron microscope.

The reliability of morphological characters to separate genetically distinct groups of mites was assessed using mites whose identity had been simultaneously confirmed from CO-I gene sequences derived from DNA extracted from leg tissue.

\section{Results}

Field observations on mite reproduction

Adults of each Tropilaelaps isolate (Tables 1,2) were producing eggs and offspring in the capped worker and drone broods of their respective honeybee host when collected. 
Analysis of CO-I gene sequences

The TCF1 and TCR2 primers amplified a single 538 DNA base-pair (bp) fragment from each mite. A BLAST search of the GenBank database on 11 September 2006 showed that a sequence obtained from mites collected from site 45 (Table 1) was most similar (88\%) to a CO-I gene sequence of the Coleopteran Bembidion rapidum [accession no. DQ059790]. It also showed $76.7 \%$ similarity with a CO-I gene sequence of Varroa destructor submitted by Navajas et al. (2002) [VDE493124] and 77.3\% similarity with a CO-I gene sequence obtained in an unpublished study by the senior author from V. jacobsoni [EF025469]. These Varroa sequences differed by $6.6 \%$ and were used as outgroup in our phylogenetic analyses.

A total of 46 haplotypes (mites with distinct mtDNA gene sequences) were found among the 89 isolates examined (the isolate from $A$. cerana is not included, but is discussed below), 45 of which were parasitising A. dorsata, 2 A. laboriosa and 11 A. mellifera. Each haplotype collected from $A$. dorsata was named after the country or island from which it was first isolated and then numbered according to its order of discovery at that location (e.g. Borneo 1, Borneo 2). Some of these haplotypes had first been identified as T. koenigerum from their morphology and hence were similarly labelled, except "Tk" was prefixed to their place of origin (e.g. TkBorneo 1). One of two haplotypes collected from A. laboriosa in Vietnam was also present on A. dorsata in Thailand and hence was named after that mite, but the other, which was morphologically different, was labelled 'TtVietnam 1'. The 11 haplotypes collected from A. mellifera had also been found on A. dorsata and were therefore given the same names as given to those mites. Exceptions to this naming system were a 'mainland Asia' haplotype, which was found to be relatively common on A. dorsata on mainland Asia from the beginning of the study, and a 'Lombok-Sumbawa' haplotype, which was found on $A$. dorsata on the Indonesian islands of Lombok and Sumbawa almost simultaneously (Tables 1,2). GenBank accession numbers for sequences of each haplotype are given in Table 1.

The alignment of $48 \mathrm{CO}-\mathrm{I}$ gene sequences (two of which were Varroa sequences) consisted of 538 base positions with no gaps. Of these, 200 bases were variable and 175 were parsimony informative, 124 at the third codon position. Within the ingroup (that is, with Varroa sequences excluded) there were 141 variable characters, 126 of which were parsimony informative. Comparisons showed that the ingroup and outgroup sequences were affected by substitution saturation and base composition heterogeneity. Within the ingroup, none of the substitutions were saturated and base composition heterogeneity was not detected.

Phylogenetic analyses, performed under all three optimality criteria (maximum parsimony, maximum likelihood and neighbour-joining) produced similar results. Hence, only the maximum parsimony analyses are reported. An unweighted parsimony analysis yielded 160 trees (length $419, \mathrm{CI}=0.6014, \mathrm{RI}=0.8879$ ). The strict consensus of these trees divided the 46 ingroup haplotypes into four main lineages (Fig. 2): Clade 1 (comprising isolates collected from A. dorsata throughout mainland Asia and the Indonesian archipelago, except Sulawesi Island. One of these isolates was also collected from A. laboriosa (Table 1) and several were also found on A. mellifera (Table 2)); Clade 2 (comprising isolates collected from A. dorsata in the Philippine Islands and the Indonesian island of Sulawesi, which borders the Philippines. Several of the Philippine isolates were also found on A. mellifera (Table 2)); Clade 3 (comprising isolates collected from A. dorsata in mainland Asia and Indonesia that were identified as T. koenigerum from morphology) and linage A (a single isolate collected from A. laboriosa in a mountainous region of North 


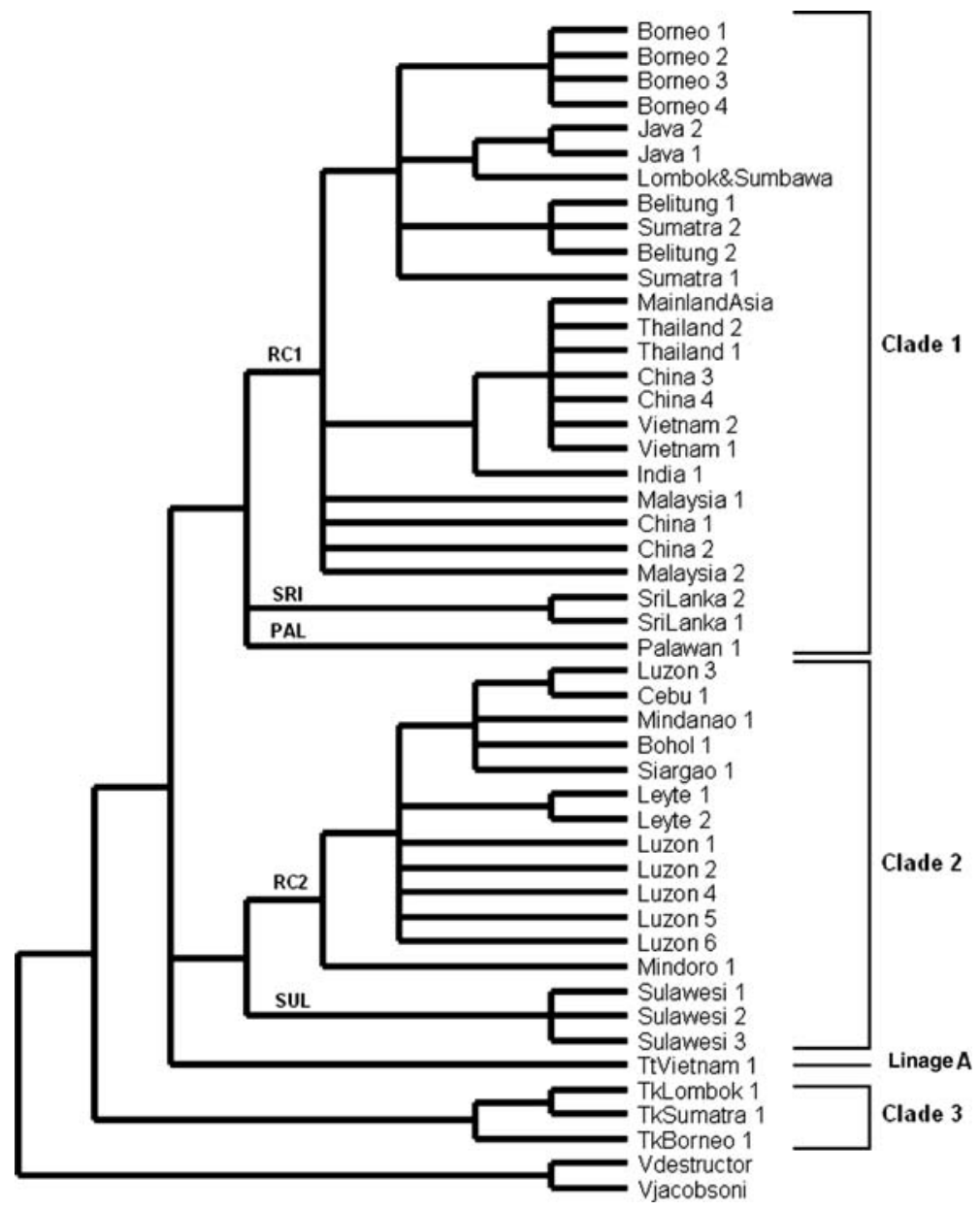

Fig. 2 Strict consensus tree from an unweighted parsimony analysis of mitochondrial COI gene sequences obtained from Tropilaelaps mites. Clades labelled RC1, SRI, PAL, RC2 and SUL were separated for calculating genetic distances (Table 3)

Vietnam). In the consensus tree Clade 3 was recovered as sister to a group consisting of Clade 1, Clade 2 and linage A, although this relationship was not subsequently supported by bootstrap analyses (Fig. 3). Within Clade 1, a Palawan group (labelled 'PAL' in Fig. 2) and two Sri Lanka haplotypes (SRI) were also consistently found outside the remaining haplotypes, which formed a monophyletic group (RC1). Similarly, within Clade 2, three Sulawesi haplotypes (SUL) were consistently found sister to the remaining haplotypes (RC2).

A parsimony tree estimation model with transversions given twice the weight of transitions yielded 80 trees (length $=547, \mathrm{CI}=0.6417, \mathrm{RI}=0.8981$ ). The consensus of these trees differed from the unweighted consensus tree only in the placement of linage A as sister to Clade 2, although again, this relationship was not subsequently supported by bootstrap analyses (Fig. 3). Differential down weighting of third codon positions had no effect on the composition of or relationships between the four ingroup groups. 


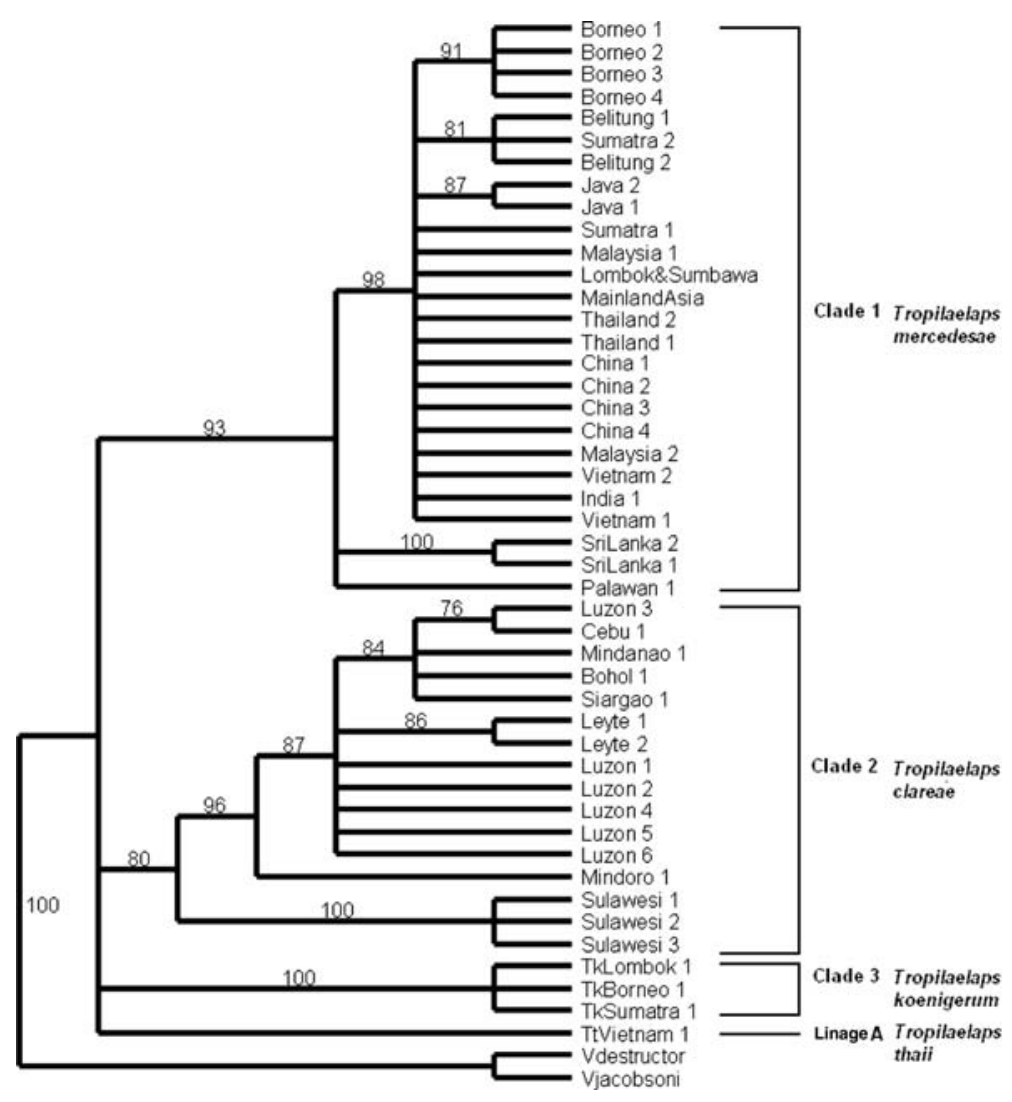

Fig. 3 Majority rule consensus tree for unweighted parsimony bootstrap (1000 pseudo-replicates)

The branch that connects the outgroup taxa is significantly longer than any other branch in the tree, accounting for $25 \%$ of the total tree length under transversion-weighted parsimony. The length of this branch and substitution saturation along its length as well as base composition heterogeneity are all factors that can force tree-topology errors during phylogenetic tree estimation (Felsenstein 1978; Lockhart et al. 1992; Simmons et al. 2004). Analyses done without the outgroup had no effect on ingroup relationships as far as they affected the consensus trees. Therefore there is no evidence for this branch having biased the estimate of ingroup relationships, although the findings of base composition heterogeneity and substitution saturation make us unable to specify with confidence the position of the root of the tree.

Bootstrap analyses using weighted and unweighted parsimony confirmed that the four ingroup groups were well supported by these data (Fig. 3). The branching order within each clade was consistent across weighting schemes, with well-supported relationships in Clade 1 between Sri Lanka(SRI)-Palawan(PAL)-remaining haplotypes (RC1) (bootstrap score $=93 \%$ ) and in Clade 2 between Sulawesi(SUL)-remaining haplotypes (RC2) (bootstrap score $=80 \%$ ). The branching patterns within the two large clades (Clades 1 and 2) were unresolved across the weighing schemes employed.

Since the relationships SRI-PAL-RC1 and SUL-RC2 (Fig. 2) were consistently found, these five groups were divided for the purposes of distance calculations and compared with 
Table 3 Matrix of uncorrected pairwise distances (percent) between the four main lineages (Clade 1 RC1, Clade 2 RC2, Clade 3 and lineage A) and sub-taxa of Clades 1 (SRI and PAL) and Clade 2 (SUL) (labelled $1-7)$ resolved in the CO-I and ITS1-5.8S-ITS2 sequence analyses

\begin{tabular}{lrrrrrrr}
\hline & 1 & \multicolumn{1}{c}{3} & \multicolumn{1}{c}{3} & 4 & 5 & \multicolumn{1}{c}{6} & 7 \\
\hline 1 Clade 1 (RC1) & 1.2 & 12.0 & 14.7 & 12.0 & 6.6 & 6.5 & 12.7 \\
2 Clade 2 (RC2) & 1.3 & 1.4 & 13.6 & 11.2 & 12.2 & 11.2 & 7.8 \\
3 Clade 3 & 5.2 & 4.9 & 1.2 & 13.6 & 14.5 & 14.9 & 14.4 \\
4 Linage A & 1.3 & 1.9 & 5.9 & $n / a$ & 11.2 & 11.3 & 10.6 \\
5 Clade 1 (SRI) & 0.4 & 1.2 & 5.0 & 1.1 & 0.2 & 4.9 & 11.0 \\
6 Clade 1 (PAL) & 0.6 & 1.3 & 4.8 & 1.3 & 0.2 & $n / a$ & 12.0 \\
7 Clade 2 (SUL) & 1.3 & 0.4 & 5.1 & 1.9 & 1.2 & 1.3 & 0.5 \\
\hline
\end{tabular}

Distances based on CO-I gene are shown above the diagonal, distances based on ITS1-5.8S-ITS2 sequences are shown below the diagonal. Numbers in italics on the diagonal indicate within clade distances based on the CO-I sequences. Where a comparison is between two individual sequences we report that pairwise distance. Where it is between an individual and a clade, or a clade and a clade, we report the mean of all individual pairwise distances involved in the comparison

Clade 3 and linage A. The results are shown in Table 3. Mean uncorrected pairwise distances among haplotypes within each of the seven groups ranged from 0.2 to $1.4 \%$, whereas distances between the 7 groups ranged from 4.9 to $14.9 \%$. Distances between SRIPAL (4.9\%), SRI-RC1 (6.6\%), PAL-RC1 (6.5\%) and SUL-RC2 (7.8\%) haplotypes were not as great as the distances between the four main groups with the SRI, PAL and SUL groups excluded (11.2-14.7\%), which, in turn, were similar to distances between the four groups with these sub-groups included (11.1-14.7\%, not shown in Table 3). The distances among individuals within each of the four main groups with the sub-groups included ranged from $1.2-3.5 \%$ (also not shown in Table 3).

Identity of Tropilaelaps collected from A. cerana

The single adult female Tropilaelaps and one of the two white nymphs collected from $A$. cerana in northern Thailand were identified as the mainland Asia haplotype of Clade 1 (Fig. 2).

Analyses of ITS1-5.8S-ITS2 sequences

The ITS4 and ITS5 primers amplified a single DNA fragment from each of the 46 mitochondrial haplotypes. Seven different sequences were found, which corresponded with Clades 1, 2 and 3, linage A, the two subclades of Clade 1 and the single subclade of Clade 2 from the CO-I analyses. One sequence, of $522 \mathrm{bp}$, was obtained from the Palawan 1 (PAL) haplotype of Clade 1 (Fig. 2) [GenBank accession no. EF025471]. Another, of $523 \mathrm{bp}$, was obtained from each of the two Sri Lanka (SRI) haplotypes of Clade 1 [EF025472], and another, of $522 \mathrm{bp}$, was obtained from each of the 23 remaining haplotypes of Clade 1 (RC1) [EF025476]. A single sequence of $525 \mathrm{bp}$ was obtained from each of the three Sulawesi sister haplotypes (SUL) of Clade 2 [EF025473], and a $526 \mathrm{bp}$ sequence was obtained from each of the 13 remaining haplotypes of Clade 2 (RC2) [EF025474]. Another sequence of $525 \mathrm{bp}$ was obtained from each of the three haplotypes of Clade 3 [EF025475] and another of $525 \mathrm{bp}$ from the sole haplotype of linage A [EF025477]. 
A BLAST search of the GenBank database on 12 September 2006 showed that our EF025476 sequence was 99\% similar to a $T$. clareae ITS1-5.8S-ITS2 sequence from Thailand [AF544013], and 94\% similar to an ITS1-5.8S-ITS2 sequence from T. koenigerum from Thailand [AF544014], both submitted by Tangjingjai et al. (2003). It also showed $73.8 \%$ similarity with a 534 bp sequence of the ITS1-5.8S-ITS2 region that the principal author had obtained from a Java haplotype of $V$. jacobsoni in an unpublished study [EF025470]. This Varroa sequence was used as an outgroup in our phylogenetic analyses. Our EF025475 sequence also showed 97\% similarity to AF544014 and 93\% similarity to AF544013.

Alignment of the eight sequences contained 34 gaps that were recoded following Simmons and Ochoterena (2000). The final alignment including recoded gaps consisted of 522 characters of which 164 were variable and 14 were parsimony informative. PTP tests for these sequences failed to reject the null hypothesis of no hierarchical signal $(P=0.069)$ and thus no further phylogenetic analyses were carried out.

Since the seven ITS1-5.8S-ITS2 sequences correspond to the four main and three subgroups resolved in the CO-I analyses, their pairwise (uncorrected) distances are also presented with those groups in Table 3. Distances between sequences that correspond to the 4 main CO-I haplotype lineages, with sequences corresponding to the PAL, SRI and SUL groups excluded, ranged from 1.3 to $5.9 \%$. Lesser distances from 0.4 to $0.6 \%$ were found between the sequences that corresponded to the PAL-SRI-RC1 haplotypes and $0.4 \%$ between the sequences corresponding to the SUL-RC2 haplotypes.

Restriction enzyme markers for identifying Tropilaelaps mites

Target sites for the restriction enzymes FauI, BsrI, Bst $Y \mathrm{I}$ and $S w a \mathrm{I}$ as well as for Bme1580I, $P s i$, and RsaI were located within the CO-I and ITS1-5.8S-ITS2 sequences, respectively (Figs. 4, 5). Digestion of PCR-amplified CO-I or ITS1-5.8S-ITS2 DNA from single unidentified mites using each of the four or three enzymes of each set allowed for those mites to be rapidly assigned to their correct linage (Fig. 6).

\section{Morphological differences}

Some morphological characters that were previously used to separate T. clareae and T. koenigerum (Delfinado-Baker 1961; Delfinado-Baker and Baker 1982) were found to be highly variable among haplotypes of Clade 1 . Most variable were characters of the ventral sternal, epigynial and anal plates, such as their shape, layering, sclerotic thickening and reticulated patterns (Fig. 7). Moreover, overlapping of the anterior margin of the anal plate by the apex of the epigynial plate in adult females, a character previously used to quickly separate female Tropilaelaps from their respective males, was found to be an artefact caused by mounting female mites on glass slides, although it was also characteristic of unmounted non-gravid females. In unmounted gravid females these plates were often well separated, as they are in males. Also, adults of the four main haplotype groups of Fig. 2 shared many morphological characters, such as body shape (elongated) and body colour (light brown), gnathosoma and peritreme structure and prominent setae on the anal plate (a pair of adanal setae and a single longer postanal seta), the epigynial plate (a single pair of setae), the sternal plate ( 3 pairs of setae) and the gnathosoma ( 3 pairs of unequally long hypostomal setae). Their papal apoteles (claws) were also simple, not forked.

Despite these character similarities and viabilities, consistent differences were found between members of the four main taxa, which are summarized as follows. 


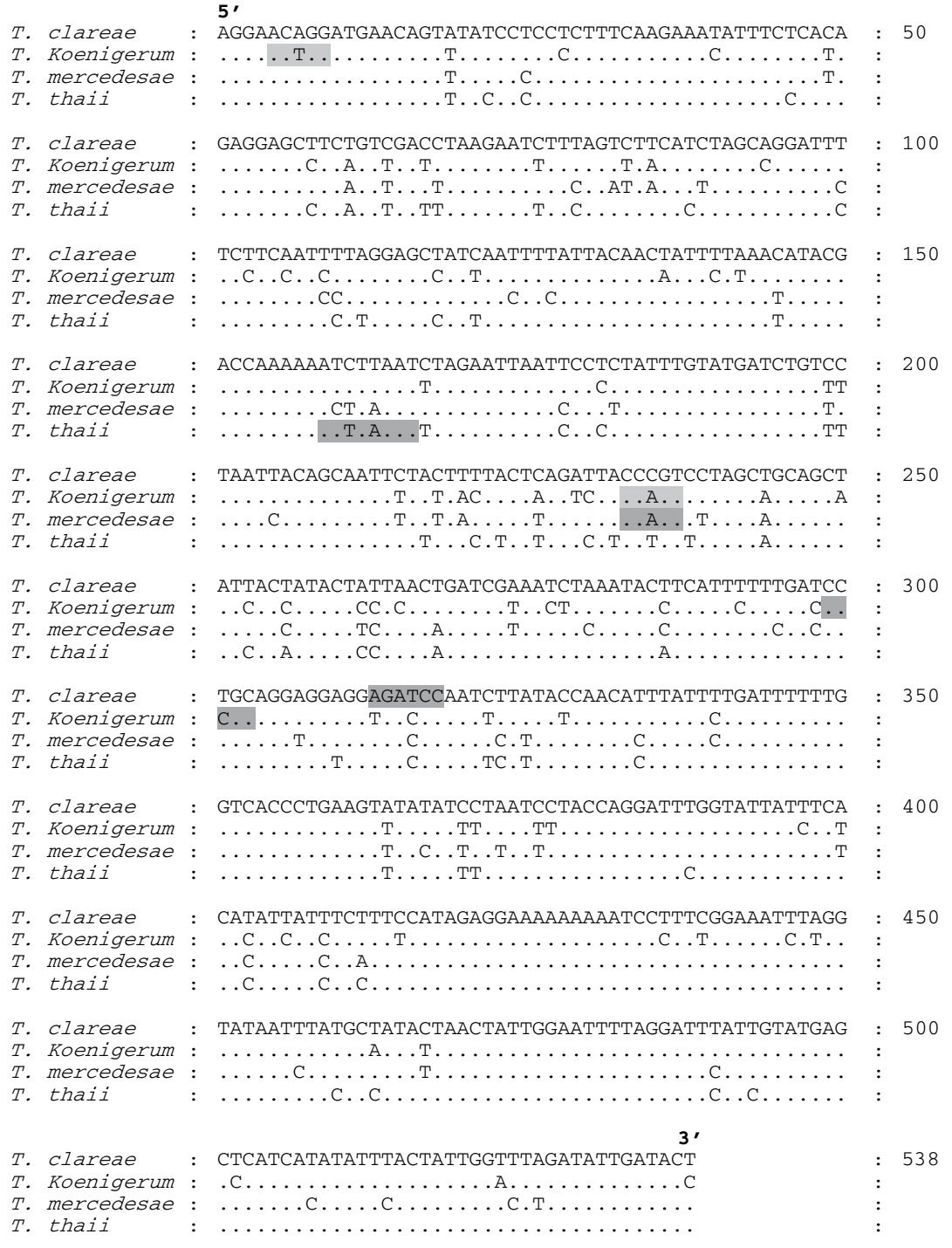

Fig. 4 Alignment of CO-I gene sequences of members of each of the four lineages resolved in this study. Shown are sequences of the Luzon 1 haplotype of Clade 2 (T. clareae), Borneo 1 haplotype of Clade 3 ( $T$. koenigerum), mainland Asia haplotype of Clade 1 (T. mercedesae) and the TtVietnam haplotype of lineage A (T. thaii). Dark shading indicates a Bst YI site in the T. clareae sequence (nucleotides 313-318), a FauI site in the T. koenigerum sequence (299-303), a BsrI site in the T. mercedesae sequence (233-237) and a Swa I site in the $T$. thaii sequence (159-166). Light shading indicates two BsrI sites in the T. koenigerum sequence. These enzymes can be used as a set to identify unknown mites to their correct taxa (Fig. 6)

Clade 1. Female: Larger than female of the other groups (Table 4), apex of the epigynial plate varies from bluntly pointed to sharply pointed (Fig. 7), small subapical tooth on the movable chela of chelicerae (Fig. 8). Male: Slightly smaller than female (Table 4), movable chela functions as spermatodactyl (sperm transfer organ) and is long and attenuate with spirally coiled apex (Fig. 9). 


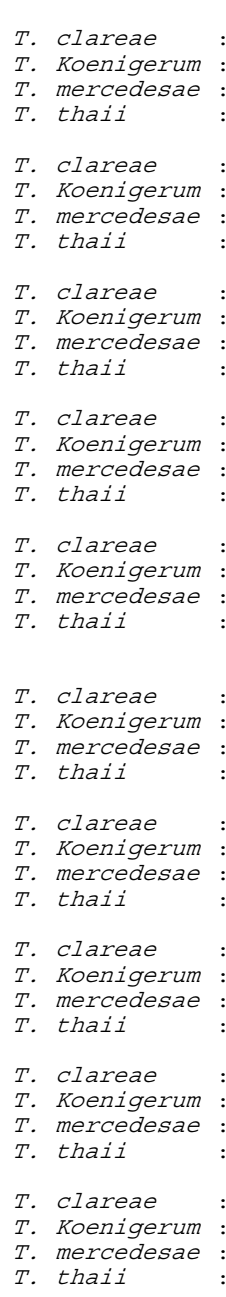

T. Clareae
T. Koenigerum
T. mercedesae
T. thaii

\section{5' $18 \mathrm{~s}$ ITS1}

CGTAGGTGAACCTGCGGAAGGATCATTACTGTCGCAAAGTCCATTCACTC

$\ldots \ldots \ldots \ldots \ldots \ldots \ldots \ldots \ldots \ldots \ldots \ldots$

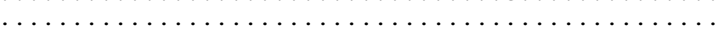

CGTCGGCGAGCGAGTGGTGCTCGAATGATGTTCTAACCCGCTCCTCTCCG

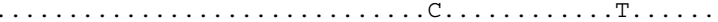

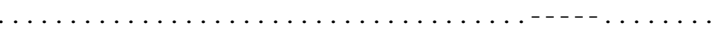

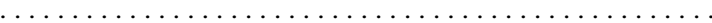

CGGAGGCGGGCGGGAGAGGCATCTGTGTCCAGTATCGTATGTATTCTATT

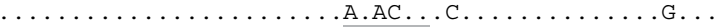
$\ldots \ldots \ldots$. ................. $\ldots \ldots \ldots$ A. . . . . . . . . . . . . .

CGTATTGCGATCTGACTTCGGCTGTGAAGTTAGGCGCGCGTCGCCGGTGC

$\ldots . . . . . . . \ldots \ldots \ldots . . \ldots \ldots$
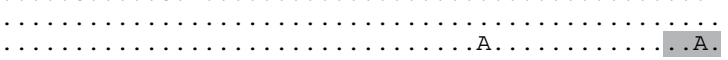

GTCCGGTTTGACATGCTTTTTCCATTTAACTCGTGCTATGGAGAAA- - - A

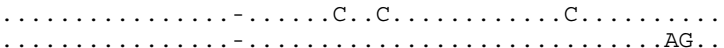

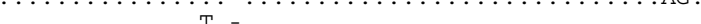

\section{$5.8 \mathrm{~s}$}

AGAACGCATCAGGACTCAATATGGGGGATCACTTAGTCCTTAAATCGATG

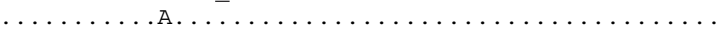

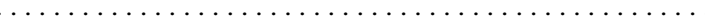

AAAAACATTGTAATTTGTGGAAATTGATGTGAGTTGTGAAATTTTGTGAG

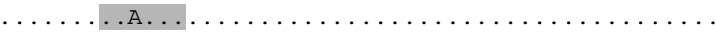
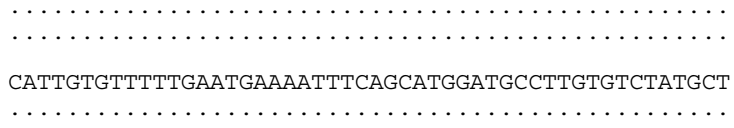

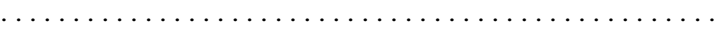

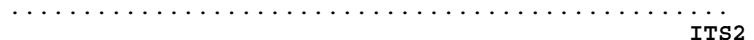

ACACTTGTTTCAGTATATAACTCGTACTATAGGTACTTACTATTGCCGCT

$\ldots \ldots \ldots \ldots \ldots \ldots \ldots \ldots \ldots \ldots \ldots$. $\ldots \ldots \ldots \ldots \ldots \ldots$

$\ldots \ldots \ldots \ldots \ldots \ldots \ldots \ldots \ldots \ldots$ G.

ACGCAATGGTATAAAATCTCCACGGTCACGAGAGTGATGGTGCCTGCTCA

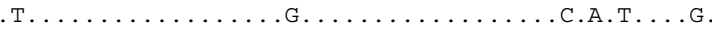

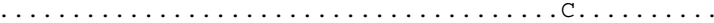

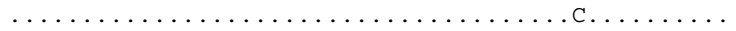

$28 \mathrm{~s}$

$3^{\prime}$

ACCTGACGTGTATCTGAAATCAAGTGTGA

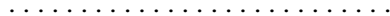

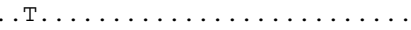

Fig. 5 Alignment of ITS1-5.8S-ITS2 sequences of members of each of the four lineages resolved in this study. Sequences are from the same haplotypes as used in Fig. 4. Underlined nucleotides in the T. clareae sequence indicate the start of each gene (after Navajas et al. 1998). Dark shadings indicate a Psi site in the $T$. koenigerum sequence (nucleotides 308-313), a Bme 1580 I site in the T. mercedesae and T. thaii sequences (125-130) and a $R s a$ I site in the T. thaii sequence (197-200), and light shading indicates another Rsa I site in all sequences. These enzymes can also be used as a set to identify unknown mites to their correct taxa (Fig. 6)

Clade 2. Female: Smaller than female of clade 1 but similar to female of linage A (Table 4), apex of epigynial plate bluntly pointed, never sharply pointed as in some females of Clade 1 (Fig. 7), same small subapical tooth on the movable chela as female of Clade 1 (Fig. 8). Male: Similar to male of Clade 1, but smaller (Table 4).

Clade 3. Female: Considerably smaller than females of the other groups (Table 4), characteristic 'pear-shaped' anal plate (Fig. 7), a pronounced subapical tooth on the moveable 

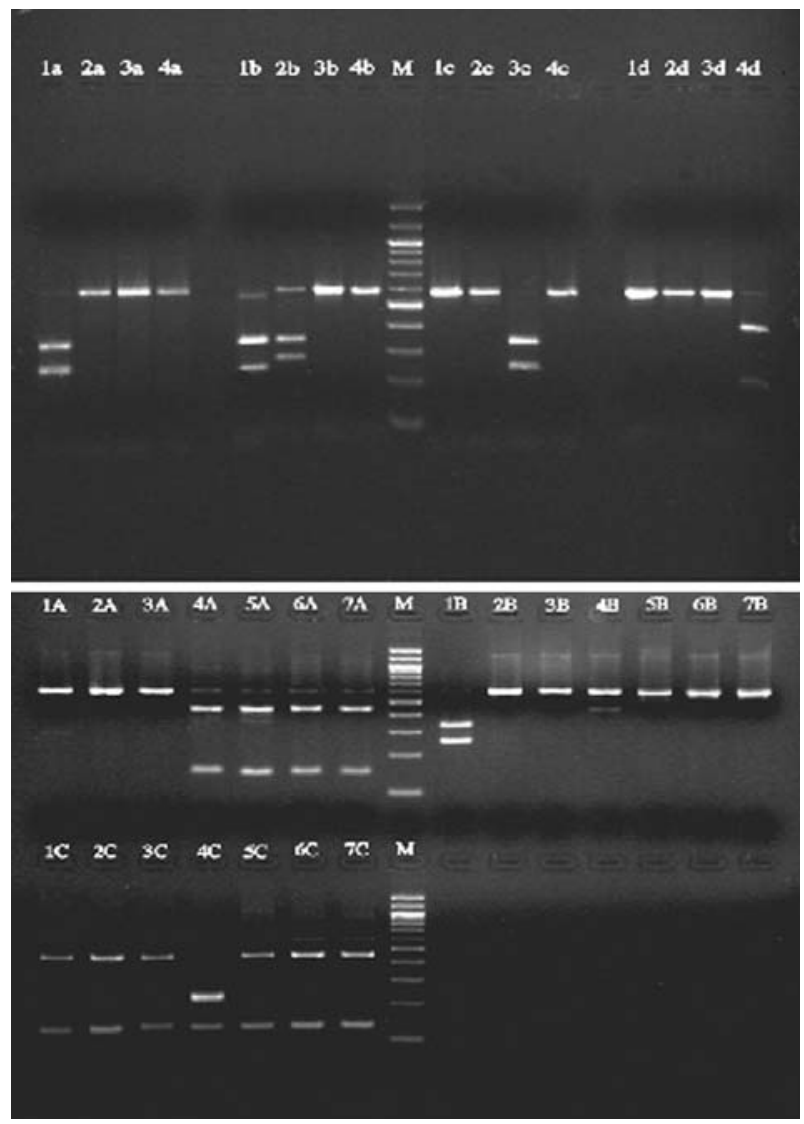

Fig. 6 Identification of Tropilaelaps mites by restriction enzyme analyses. Top: Bands produced when PCRamplified CO-I gene fragments of mites representing each of the four lineages resolved in this study were digested with the FauI, BsrI, Bst YI and $S w a I$ restriction enzymes (labelled a-d respectively). Lane $1=T$. koenigerum (Clade 3; Borneo 1 haplotype), $2=T$. mercedesae (Clade 1; mainland Asia haplotype), $3=T$. clareae (Clade 2; Luzon 1 haplotype), $4=T$. thaii (lineage A; TtVietnam haplotype), $\mathrm{M}=100$ bp DNA ladder. Bottom: Bands produced when PCR-amplified ITS1-5.8S-ITS2 genes of each of the four CO-I lineages and sub-taxa of Clades 1 and 2 of Fig. 2 (1-7) were digested with Bme 1580I (A), PsiI (B) and RsaI (C). Lane $1=T$. koenigerum (Clade 3; Borneo 1 haplotype), $2=T$. clareae (Clade $2 \mathrm{RC}$; Luzon 1 haplotype), $3=T$. clareae (Clade 2 SUL; Sulawesi 1 haplotype), $4=T$. thaii (lineage A; TtVietnam 1 haplotype), $5=T$. mercedesae (Clade $1 \mathrm{RC}$; mainland Asia haplotype), $6=$ T. mercedesae (Clade $1 \mathrm{SRI}$; Sri Lanka 1 haplotype), $7=T$. mercedesae (Clade 1 PAL; Palawan 1 haplotype), $\mathrm{M}=100 \mathrm{bp}$ DNA ladder

chela (Fig. 8). Male: Smaller than female (Table 4), chela-spermatodactyl short with a distinct 'pig-tail' loop at apex (Fig. 9).

Taxon A. Female: Similar in size to female of Clade 2 (Table 4), anal plate 'bell-shaped' (Fig. 7), lacks subapical tooth on the movable chela (Fig. 8). Male: No males were collected.

\section{Sex ratios}

Females were more common than males among specimens collected of the four main haplotype groups (Table 2), regardless of the bee host from which they were collected. For 

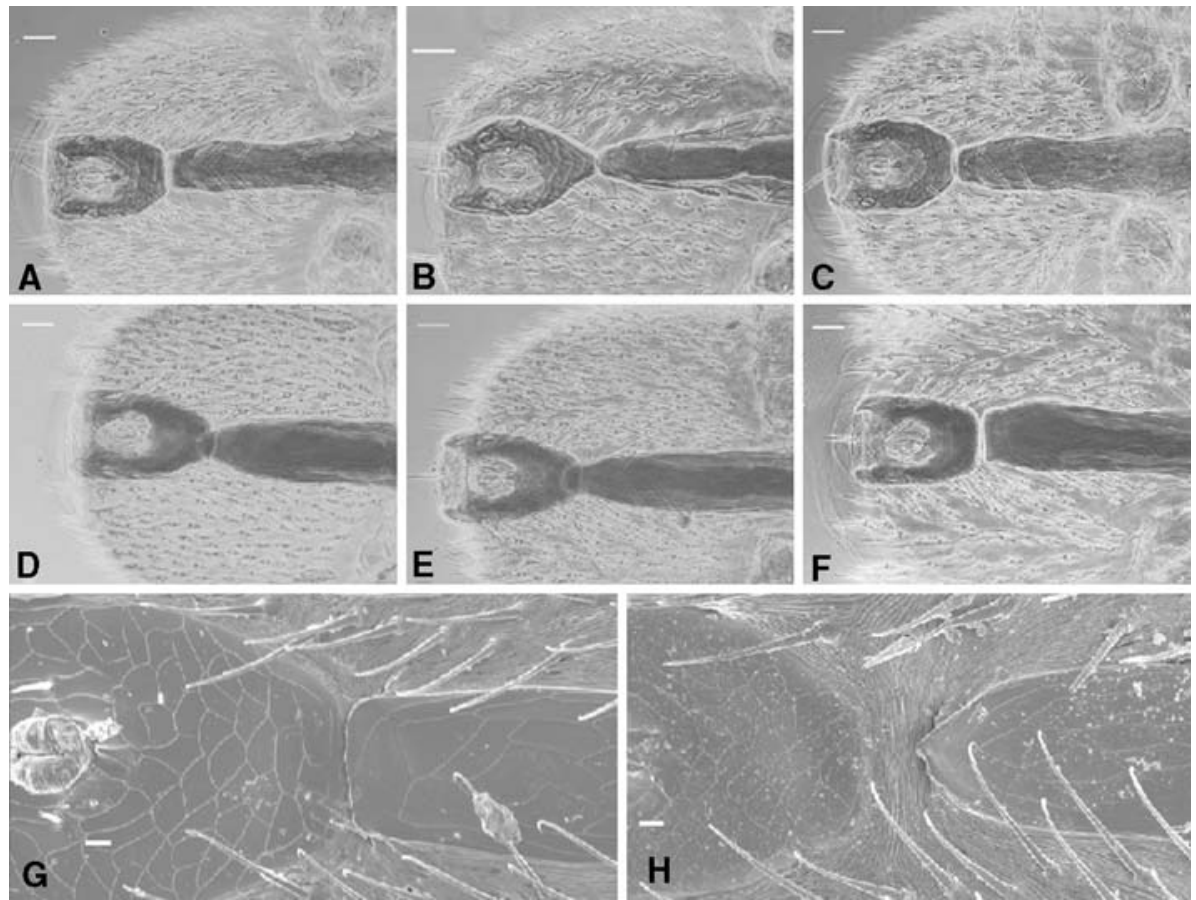

Fig. 7 A-F: Light microscope view of the ventral plates of adult female Tropilaelaps. A, bluntly pointed apex of epigynial plate of Luzon 1 haplotype of Clade 1 (T. clareae). B, pear-shaped anal plate of Borneo 1 haplotype of Clade 3 (T. koenigerum). C, slightly bell-shaped anal plate TtVietnam haplotype of lineage A (T. thaii). D-F, variation in the shape of the apex of the epigynial plate (from pointed to bluntly pointed) in Java 1, Vietnam 1 and India 1 haplotypes respectively of Clade 1 (T. mercedesae). Bars $=50 \mu \mathrm{m}$. G, H: SEM close-ups of the anal and epigynial plates of a Thailand 1 and Java 1 haplotype of Clade 1 (T. mercedesae) demonstrating variation in the apex of the epigynial plates and reticulated patterns of the anal and epigynial plates. Bars $=10 \mu \mathrm{m}$

specimens of Clade 1, which were collected from A. dorsata, the female:male ratio was 5.5:1 $(n=1059)$, whereas it was 5.1:1 $(n=460)$ for Clade 2 and 31:1 $(n=32)$ for Clade 3. No males of linage A were collected $(n=18)$. Among specimens of Clade 1 collected from A. mellifera the female:male ratio was 8.7:1 $(n=1884)$ and, for Clade 2, 8.5:1 $(n=370)$.

\section{Discussion}

Our results indicate that the genus Tropilaelaps contains at least four distinct species, not two, as currently recognized. Studies on variation in the mtDNA CO-I gene of 89 widespread Tropilaelaps isolates uncovered 46 different haplotypes that were resolved by parsimony analyses into 4 well-defined lineages ( 3 clades and a lineage with a single member, Fig. 2). Each clade was well-supported by unweighted parsimony bootstrap (Fig. 3). The uncorrected pairwise distances within and between the lineages ranged from 1.2 to $3.5 \%$ and 11.1-14.7\%, respectively. Studies on this gene in other Acari have shown $2.5 \%$ and $16 \%$ sequence divergence within and between species of Stratiolaelaps (same family as Tropilaelaps) (Walter and Campbell 2003), and 0-2.1\% and 6.1-9.1\% within and between species of Varroa (same order as Tropilaelaps) (Anderson and Trueman 2000). Similar 
Table 4 Mean body lengths and widths (with standard deviations (SD)) of adult female (F) and male (M) mites in the four main taxa (or species) resolved by CO-I analyses and collected from A. dorsata (Ad), A. mellifera $(\mathrm{Am})$ and A. laboriosa $(\mathrm{Al})$

\begin{tabular}{|c|c|c|c|c|c|c|c|}
\hline Taxa (Species) & Sex & Host & $\begin{array}{l}\text { Length } \\
(\mu \mathrm{m})\end{array}$ & SD & $\begin{array}{l}\text { Width } \\
(\mu \mathrm{m})\end{array}$ & SD & $n$ \\
\hline \multirow[t]{4}{*}{ Clade 1 (T. mercedesae) $\{3,6,16,19,42,0, \mathrm{~L}, \mathrm{jj}\}$} & $\mathrm{F}$ & Ad & 994.1 & 23.9 & 548.8 & 23.2 & 89 \\
\hline & M & Ad & 927.1 & 15.4 & 527.3 & 18.9 & 11 \\
\hline & $\mathrm{F}$ & Am & 956.1 & 27.6 & 533.2 & 21.1 & 60 \\
\hline & M & Am & 907.4 & 9.2 & 514.1 & 18.3 & 5 \\
\hline \multirow[t]{4}{*}{ Clade 2 (T. clareae) $\{25,30,34,38, \mathrm{R}, \mathrm{X}, \mathrm{W}\}$} & $\mathrm{F}$ & Ad & 884.8 & 21.4 & 483.9 & 15.4 & 90 \\
\hline & M & Ad & 852.4 & 14.9 & 501.7 & 9.9 & 9 \\
\hline & $\mathrm{F}$ & Am & 877.3 & 27.4 & 486.3 & 13.1 & 58 \\
\hline & M & Am & 858.6 & 16.7 & 500.5 & 10.0 & 19 \\
\hline \multirow[t]{2}{*}{ Clade 3 (T. koenigerum) $\{7,17\}$} & $\mathrm{F}$ & Ad & 693.5 & 12.8 & 427.6 & 13.5 & 10 \\
\hline & M & Ad & 575.5 & & 383.7 & & 1 \\
\hline Taxon A (T. thaii) $\{53\}$ & $\mathrm{F}$ & $\mathrm{Al}$ & 890.1 & 4.9 & 491.8 & 12.9 & 6 \\
\hline
\end{tabular}

$n=$ number of specimens examined. Numbers inside \{\} brackets correspond with sites in Tables 1 and 2 from which mites were measured
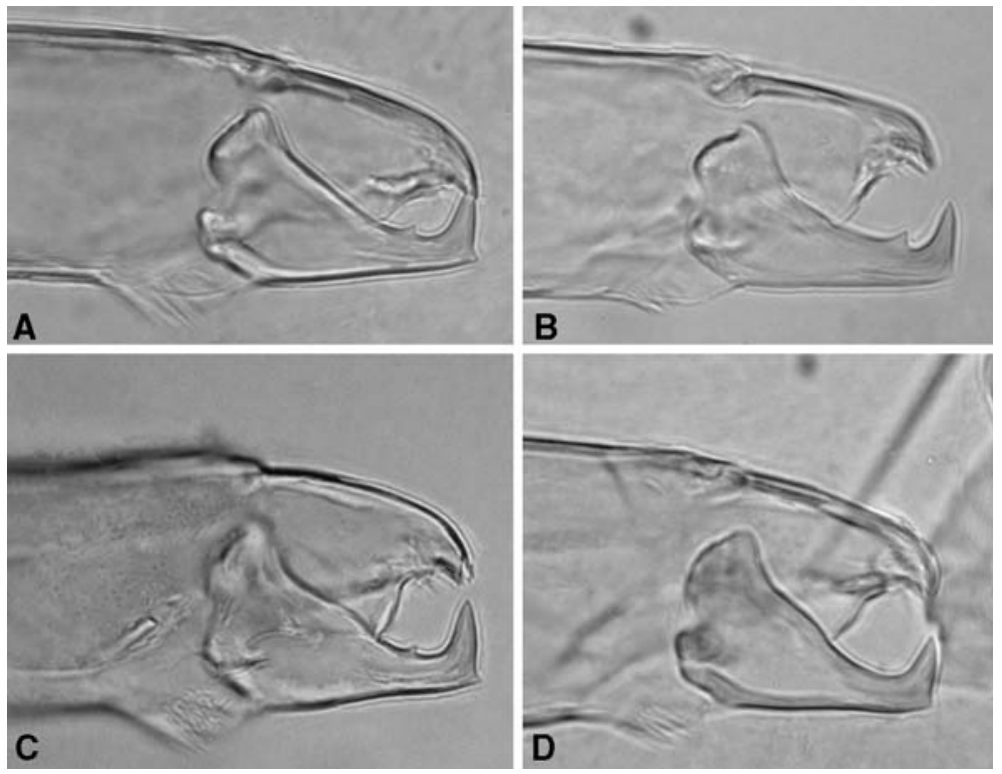

Fig. 8 Adult female chelicerae of A: Clade 2 (T. clareae), B: Clade 3 (T. koenigerum), C: Clade 1 (T. mercedesae), and D: lineage A (T. thaii) (light microscopy, $\times 800)$

levels of divergence have also been reported for this gene in isolates of cassava green mite (Mononychellus Progresivus) and between species of spider mites in the genus Tetranychus (Navajas et al. 1994). Indeed, the large divergences between the four lineages resolved here would be unprecedented for arthropods belonging to the same species, and are more in line with the $11 \%$ sequence divergence reported for the CO-I gene between the genera Tetranychus and Mononychellus (Navajas et al. 1994), 9.7-13.9\% between Tetranychus and Amphitetranychus (Navajas et al. 1998) and 10.6-13.3\% between Tetranychus and Panonychus (Toda et al. 2000). Hence, we conclude that the distances within and 


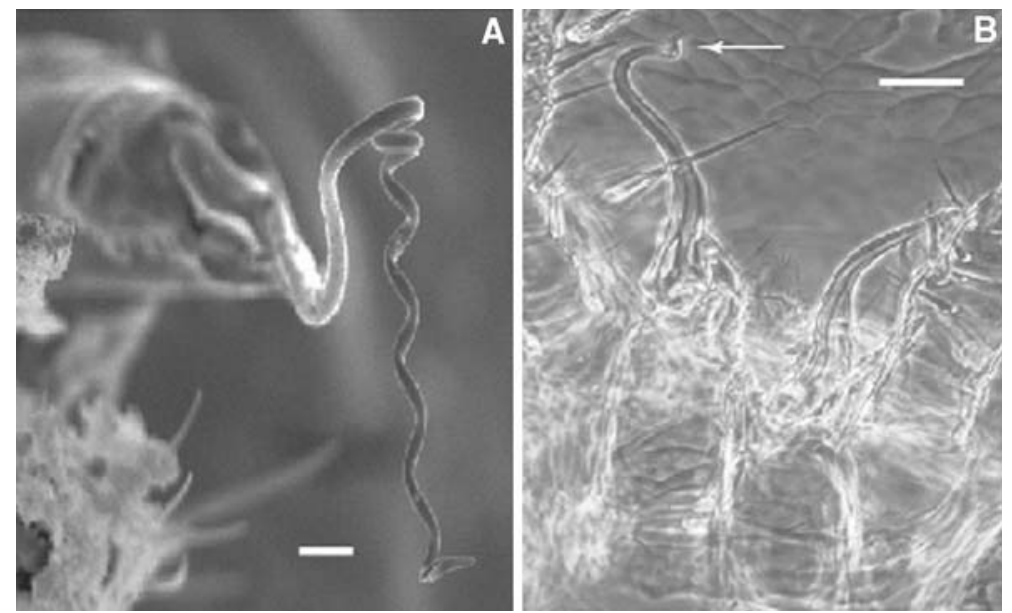

Fig. 9 A: SEM close-up of the coiled apex of male chela spermato dactyl of Luzon 1 haplotype of Clade 2 (T. clareae), which is identical to that of male of Clade 1 (T. mercedesae). Bar $=10 \mu \mathrm{m}$. B: Light microscope view of pig-tail-like loop at the apex of male chela spermato dactyl of the Borneo 1 haplotype of Clade 3 ( $T$. koenigerum (arrow), bar $=10 \mu \mathrm{m}$

between CO-I haplotypes of the four lineages resolved here are small and large enough to represent differences within and between species respectively. The lineage with the most haplotypes (Clade 1, Fig. 2) also contained haplotypes (labelled SRI and PAL) whose sequences differed from the remaining haplotypes of the clade by $6.6 \%$ and $6.5 \%$ respectively. Similarly, sequences of mites labelled SUL in the second largest lineage (Clade 2) differed from the remaining mite haplotypes of Clade 2 by $7.8 \%$. These differences may well be large enough to represent interspecies differences, but here we consider those mites as subclades of their respective clades, pending further data. Bootstrap analyses (Fig. 3) also support this conclusion.

Morphological data also supports four species of Tropilaelaps. Adults of clades 1 and 2 differed in body size but otherwise were most alike, and this undoubtedly has led to them being mistaken as members of the same species. Adults of Clade 3 were smaller than the other groups. The females also differed in the structure of their ventral anal plate and subapical tooth of the chelicerae, and the male differed from that of Clade 1 and 2 in the structure of its chela-spermatodactyl. Females of linage A were similar in size to Clade 2, but lacked a subapical tooth of the chelicerae and showed differences in the structure of their anal plate. No males of linage A were collected. Interestingly, CO-I gene divergence was less between Clade 2 and linage A $(\sim 11 \%)$, whose members are morphologically quite different, than between Clades 1 and $2(\sim 12 \%)$, whose members are morphologically quite similar. As well, mites of Clades 1 and 3 (showing $\sim 15 \%$ CO-I divergence) were found sympatric on A. dorsata, and mites of Clade 1 and lineage A ( $12 \%$ CO-I divergence) were found sympatric on A. laboriosa, indicating that these lineages were genetically isolated. Hence, within the genus Tropilaelaps, an approximate CO-I gene sequence divergence of $11 \%$ between mites indicates that those mites are reproductively isolated. On this basis, mites of Cades 1 and 2 belong to two different species, even though they are morphologically similar.

Nuclear gene sequence data also supports four species of Tropilaelaps. Seven different ITS1-5.8S-ITS2 gene sequences were obtained from the 46 Tropilaelaps haplotypes and 
they corresponded with the four lineages and three subclades resolved in the CO-I analyses. Clearly, in Tropilaelaps this gene region shows less heterogeneity than the CO-I gene and thus, as also demonstrated in other Acari (Navajas et al. 1998; Navajas and Fenton 2000; Tangjingjai et al. 2003), is a useful marker for differentiating mites at the interspecies level. The small differences between our T. koenigerum and T. mercedesae ITS1-5.8S-ITS2 sequences and those reported by Tangjingjai et al. (2003) from Thailand (note their T. clareae sequence corresponds to our T. mercedesae sequence) most likely result from sequencing errors.

Hence, the data we have presented clearly demonstrates that the genus Tropilaelaps contains four distinct species. In a new classification, $T$. clareae is here redefined as encompassing mites of Clade 2, as that clade contains haplotypes from Luzon Island in the Philippines where T. clareae was first described (Delfinado and Baker 1961). Tropilaelaps koenigerum encompasses mites of Clade 3, as those mites were identified as $T$. koenigerum from their morphology (Delfinado-Baker and Baker 1982). Mites of Clade 1 , which have long been mistaken for $T$. clareae, belong to a new species, which we name T. mercedesae n. sp., and linage A is also a new species, which we name T. thaii $\mathrm{n}$. sp. This new classification is depicted in Fig. 3. Given the large amount of variation detected here in the CO-I gene, we predict that other Tropilaelaps haplotypes await discovery, particularly in the Nepal-Pakistan region from which we were unable to obtain isolates.

Primary host-parasite relationships and geographical distributions

Apis dorsata, which has long been considered the primary host of Tropilaelaps mites, is still undergoing taxonomic revision. Ruttner (1988) recognized four sub-species: $A$. $d$. dorsata, A. d. binghami, A. d. breviligula and A. d. laboriosa. More recently, A. laboriosa and $A$. binghami have been treated as stand-alone species, although the species status of $A$. binghami has not been confirmed (Arias and Sheppard 2005). In this study, A. laboriosa is treated as a separate species and $A$. binghami as a sub-species of $A$. dorsata.

In Asia, $A . d$. dorsata, $A$. $d$. binghami, and $A$. d. breviligula are geographically isolated, but $A$. $d$. dorsata is sympatric with A. laboriosa in Himalayan regions. Apis dorsata dorsata is found alone throughout mainland Asia and the Indonesian archipelago, except on the Indonesian island of Sulawesi (Celebes), which is inhabited by A. d. binghami. Apis dorsata breviligula is also found alone in the Philippine Islands, except on Palawan Island, which is inhabited by A. $d$. dorsata (Ruttner 1988). Our field observations on the body colour of worker honeybees as well as our laboratory studies on honeybee DNA (unpublished) verified these distributions.

In the studies here, T. clareae was found parasitising A. d. breviligula in the Philippines and $A$. $d$. binghami on nearby Sulawesi Island. Tropilaelaps mercedesae was found parasitising $A$. $d$. dorsata throughout mainland Asia and in Indonesian (except Sulawesi Island) and, in some locations, was sympatric with T. koenigerum. It was also found on the far western Philippine island of Palawan, but this is not surprising, as this island was once connected to Borneo during the Pleistocene and has a flora and fauna more similar of Borneo than the Philippines islands, which were never connected to mainland Asia (Smith et al. 2000). T. mercedesae was also found parasitising A. laboriosa in a mountainous region of Vietnam where it was sympatric with $T$. thaii. Hence, the biogeography of Tropilaelaps mites (Fig. 1) is strikingly similar to that of the giant honeybees of Asia and implies that these mites and bees have co-evolved. From these mite distributions it is evident that $A . d$. breviligula and $A$. $d$. binghami are the primary hosts of $T$. clareae, A. d. dorsata of $T$. 
mercedesae and T. koenigerum, and A. laboriosa of T. thaii. More detailed studies are needed to determine the association of A. laboriosa with T. mercedesae and T. koenigerum.

In this study $T$. mercedesae was common on $A$. $d$. dorsata in Sri Lanka even though it was previously reported as not being present there when mistaken for T. clareae (Delfinado-Baker and Baker 1982). Also, T. koenigerum was not found in Sri Lanka, even though it was first discovered there (Delfinado-Baker and Baker 1982; Koeniger et al. 1983). This suggests that, in Sri Lanka, populations of both species collapse periodically as has been reported for T. mercedesae in Thailand (when referred to as T. clareae) (Kavinseksan et al. 2004). Tropilaelaps koenigerum was also difficult to find and we predict it will eventually be found throughout the distribution range of $A$. $d$. dorsata. The studies here have extended the distribution range of this species from Sri Lanka, mainland Asia and Borneo to the Indonesian archipelago. A brief description of each of the four species of Tropilaelaps resolved here follows. In these descriptions all measurements are given in $\mu \mathrm{m}$.

Tropilaelaps clareae Delfinado and Baker

Specimens examined: Twenty (20) adult females and three adult males, PHILIPPINES, Silang, Cavite Province, Luzon Island, 11.iii.2001, in a colony of A. mellifera, D.L. ANDERSON coll., (3 females deposited with the Australian National Insect Collection, Canberra, Australia (ANIC), 2 with the British Museum of Natural History, London, UK (BMNH), 2 with the United States National Museum, Washington DC, USA (USNM) and 2 with the Museum National d'Histoire Naturelle, Paris, France (MNHN)); 15 adult females, PHILIPPINES, Guinobatan, Albay Province, Luzon Island, 19.i.2003, in a colony of A. dorsata breviligula, D.L. ANDERSON coll., (2 females deposited with ANIC, 2 with BMNH, 2 with USNM and 2 with MNHN); 19 adult females, PHILIPPINES, Carmen, Bohol Island, 11.ii.2003, in a colony of $A$. $d$. breviligula, D.L. ANDERSON coll., (3 females deposited with ANIC, 2 with BMNH, 2 with USNM and 2 with MNHN).

Female and male: A complete description of the adult female and male with accompanying figures is given by Delfinado and Baker (1961).

Remarks: Tropilaelaps clareae is redefined here as encompassing haplotypes that parasitise and reproduce on $A$. $d$. breviligula and A. mellifera brood throughout the Philippines (except Palawan Island) and also on $A$. $d$. binghami on Sulawesi Island (Fig. 1). Partial mtDNA CO-I gene sequences of the 16 known haplotypes have been deposited in GenBank (Table 1), and one of these sequences, from mites on Luzon Island where T. clareae was first described (Luzon 1 haplotype of Table 2), is shown in Fig. 4. All haplotypes from the Philippines share a common ITS1-5.8S-ITS2 gene sequence, given in Fig. 5 and three haplotypes from Sulawesi Island share a common ITS1-5.8S-ITS2 gene sequence (GenBank under accession number EF025473). Members of the species can also be identified from their restriction enzyme profiles when using a combination of FauI, BsrI, BstYI and SwaI or Bme1580I, PsiI, and RsaI to digest their CO-I or ITS1-5.8S-ITS2 DNA respectively (Fig. 6). In our studies the mean length and width of adult females was $881.9(+/$ $-24.1) \times 484.8(+/-14.5)(n=148)$ and for adult males, $856.6(+/-16.2) \times 500.9(+/$ $-9.8)(n=28)$.

Tropilaelaps koenigerum Delfinado-Baker and Baker

Specimens examined: Five (5) adult females, BORNEO, Malinau, Kalimantan, 20.iii.2004, in a colony of $A$. $d$. dorsata, D. L. ANDERSON coll., (1 female deposited with ANIC, 1 with BMNH); 5 adult females, 1 male, INDONESIA, Belanting, Lombok Island, 
2.vii.2003, in a colony of $A$. $d$. dorsata, D. L. ANDERSON coll., (1 male deposited with ANIC, 1 female with USNM, 1 female with MNHN).

Female and male: A complete description of the adult female and male with accompanying figures is given by Delfinado-Baker and Baker (1982).

Remarks: Tropilaelaps koenigerum encompasses haplotypes that parasitise and reproduce on $A$. $d$. dorsata brood in Sri Lanka, mainland Asia and Indonesia (except Sulawesi Island). Partial CO-I gene sequence of a haplotype from Borneo is shown in Fig. 4. Tropilaelaps koenigerum can also be identified from its homologous ITS1-5.8S-ITS2 gene sequence (Fig. 5) or from its restriction enzyme profile (Fig. 6). Mean length and width of adult female measured here was $693.5(+/-12.8) \times 427.6((+/-13.5)(n=10)$ and for the male, $575.5 \times 383.7(n=1)$.

\section{Tropilaelaps mercedesae $\mathrm{n} . \mathrm{sp}$.}

Named in honour of Dr Mercedes Delfinado-Baker in recognition of her contributions to the study of bee mites.

Holotype: One (1) adult female, VIETNAM, Hanoi, 01.xiii.2004, in a colony of A. mellifera, C.H. PUNG coll., deposited in ANIC.

Paratypes and Allotypes: Twelve (12) adult females 4 adult males, INDONESIA, Wamena, Papua, New Guinea Island, 20.xi.1996, in a colony of A. mellifera, D.L. ANDERSON coll., ( 3 females 2 males deposited in both ANIC and BMNH, and 3 females in both USNM and MNHN); 8 adult females 1 adult male, BORNEO, Bulungan Regency, 20.iii.2004, in a colony of $A$. d. dorsata, D.L. ANDERSON coll., ( 2 females 1 male deposited in ANIC, and 2 females in BMNH, USNM and MNHN); 8 adult females 1 adult male, INDIA, Bangalore, 1.v.2004, in a colony of $A$. $d$. dorsata, N. NAGARAJA coll., ( 2 females 1 male deposited in ANIC, and 2 females in BMNH, USNM and MNHN); 6 adult females 4 adult males, SRI LANKA, Welimada, Uva Province, 27.vii.2004, in a colony of $A$. $d$. dorsata, D. L. ANDERSON coll., (2 females 1 male deposited in both ANIC and BMNH, and 1 female 1 male in both USNM and MNHN); 3 adult females, same details as holotype (1 female deposited in BMNH, USNM and MNHN). Specimens were also examined from sites 16, 19, 41 and 42 (Table 1) and L and $\mathrm{O}$ (Table 2).

Adult female: Morphologically similar to T. clareae, but larger. Mean length and width of the dorsal plate $978.8(+/-31.5) \times 542.5(+/-23.6)(n=149)$. The shape of the apex of the epigynial plate varies from bluntly pointed to sharply pointed whereas in $T$. clareae it is always bluntly pointed (Fig. 7).

Adult male: Morphologically similar to T. clareae, but larger. Mean length and width of the dorsal plate $920.9(+/-16.5) \times 523.2(+/-19.2)(n=16)$.

Remarks: Tropilaelaps mercedesae encompasses haplotypes that parasitise and reproduce on A. d. dorsata and A. mellifera broods throughout mainland Asia and Indonesia, except Sulawesi Island (Fig. 1). It also parasitises A. laboriosa in mountainous regions near the Himalayas (Delfinado-Baker et al. 1985; this study). Partial mtDNA CO-I gene sequences of the 26 known haplotypes have been deposited in GenBank (Table 1) and a partial sequence of the holotype is shown in Fig. 4. All haplotypes share a common ITS15.8S-ITS2 gene sequence (Fig. 5), except for those from Sri Lanka and Palawan (GenBank under accession numbers EF025472 and EF025471 respectively). Members of the species can also be identified from their restriction enzyme profile (Fig. 6). 
Tropilaelaps thaii $\mathrm{n} . \mathrm{sp}$.

Named in honour of P.H. Thai who collected the specimens examined here.

Holotype: One (1) adult female, VIETNAM, Sonla Province, 13.vii.2004, in a colony of A. laboriosa, P. H. Thai coll., deposited in ANIC.

Paratypes: Four (4) adult females, same details as holotype (1 female deposited in each of ANIC, BMNH, USNM and MNHN).

Adult female: Morphologically similar to $T$. clareae, but has a slightly bell-shaped anal plate (Fig. 7) and lacks a subapical tooth on the movable chela (Fig. 8). The mean length and width of the dorsal plate $890.1(+/-4.9) \times 491.8(+/-12.9)(n=6)$.

Adult male: Not yet discovered.

Remarks: Tropilaelaps thaii has only been found on A. laboriosa in Vietnam, but is likely to be present on other populations of A. laboriosa. Members of the species can be readily identified from their partial CO-I (Fig. 4) and ITS1-5.8S-ITS2 (Fig. 5) gene sequences, and from their restriction enzyme profile (Fig. 6).

\section{Tropilaelaps infesting A. mellifera and A. cerana}

In this study, $T$. mercedesae and $T$. clareae were the only Tropilaelaps found reproducing on A. mellifera brood. Of the two species, T. mercedesae was most widely spread, and was found on A. mellifera in regions well outside of its native distribution range (Fig. 1). In coming years this mite could well spread into temperate regions, as rising temperatures from climate change cause A. mellifera in those regions to produce brood throughout the year, which the mite needs to survive (note, T. mercedesae cannot feed on adult bees and hence cannot exist for more than a few days in broodless honeybee colonies (Woyke 1984)). Human activity will also contribute to this spread as highlighted here, where the T. mercedesae found in New Guinea was the same haplotype as that present in Java (Table 2), thus confirming a report that $T$. clareae (now T. mercedesae) was introduced to New Guinea by humans on A. mellifera imported from Java (Anderson 1994). The results from this study also indicate that T. koenigerum and T. thaii are harmless to A. mellifera.

Also in this study, a single adult female T. mercedesae was found parasitising and producing offspring on A. cerana brood. This observation is the exception rather than the rule, as the mite has rarely been reported from $A$. cerana colonies and, in those few cases, it was not reported to have reproduced on the bees' brood. Understanding why T. mercedesae has not been able to widely utilize $A$. cerana as a host, despite being capable of doing so, could present new opportunities for controlling it on A. mellifera.

Acknowledgments We thank the numerous friends, colleagues and traditional 'honey-hunters' that assisted with the often-hazardous task of collecting Tropilaelaps from A. dorsata and A. laboriosa. Special thanks to W. Chandra, P.H. Chinh, C. Cervancia, L. Dulay, A.C. Fajardo Jr, T. Ken, R. Lucero, R. Maat, A. Pipe, R.W.K. Punchihewa, D. Purwanto, M.S. Reddy, A. Sito, A. Sulistianto, T. Suppasat, P.H. Thai, S. Wongsiri and T. Zhou. Ms Kerrie Medveczky and Ms Fiona Spier provided excellent technical assistance. Drs B. Halliday and M. Delfinado-Baker provided guidance and helpful suggestions with various aspects of the work and comments from Prof. A.J. Gibbs and Drs S. Fuchs and P. DeBarro helped to improve the manuscript. The study was supported by a grant from The Australian Centre for International Agriculture Research. 


\section{References}

Aggarwal K (1988) Incidence of Tropilaelaps clareae on three Apis species in Hisar (India). In: Needham GR, Page RE Jr, Delfinado-Baker M, Bowan CE (eds) Africanised honey bees and bee mites. Halsted Press, New York, pp 396-403

Anderson DL (1994) Non-reproduction of Varroa jacobsoni in Apis mellifera colonies in Papua New Guinea and Indonesia. Apidologie 25:412-421

Anderson DL, Fuchs S (1998) Two genetically distinct populations of Varroa jacobsoni with contrasting reproductive abilities on Apis mellifera. J Apic Res 37:69-78

Anderson DL, Trueman JWH (2000) Varroa jacobsoni is more than one species. Exp Appl Acarol 24:165189

Anderson DL, Gibbs AJ, Gibson NL (1998) Identification and phylogeny of spore-cyst fungi (Ascosphaera spp.) using ribosomal DNA sequences. Mycol Res 102:541-547

Archie JW (1989) A randomization test for phylogenetic information in systematic data. Syst Zool 38:239

Arias MC, Sheppard WS (2005) Phylogenetic relationships of honey bees (Hymenoptera: Apinae:Apini) inferred from nuclear and mitochondrial DNA sequence data. Mol Phylogenet Evol 37:25-35

Burgett M, Akratanakul P, Morse RA (1983) Tropilaelaps clareae: a parasite of honeybees in south-east Asia. Bee World 64:25-28

Burgett DM, Rossignol PA, Kiprasert C (1990) A model of dispersion and regulation of brood mite (Tropilaelaps clareae) parasitism on the giant honeybee (Apis dorsata). Can J Zool 68:1423-1427

Delfinado-Baker M (1982) New records for Tropilaelaps clareae from colonies of Apis cerana indica. Am Bee J 122:382

Delfinado-Baker M, Aggarwal K (1987) Infestation of Tropilaelaps clareae and Varroa jacobsoni in Apis mellifera ligustica colonies in Papua New Guinea. Am Bee J 127:443

Delfinado MD, Baker EW (1961) Tropilaelaps, a new species of mite from the Philippines (Laelaptidae [s. lat]: Acarina). Fieldiana Zool 44:53-56

Delfinado-Baker M, Baker EW (1982) A new species of Tropilaelaps parasitic on honey bees. Am Bee J 122:416-417

Delfinado-Baker M, Underwood BA, Baker EW (1985) The occurrence of Tropilaelaps mites in brood nests of Apis dorsata and A. laboriosa in Nepal, with descriptions of the nymphal stages. Am Bee J 125:703706

Delfinado-Baker M, Baker EW, Phoon ACG (1989) Mites (Acari) associated with bees (Apidae) in Asia, with description of a new species. Am Bee J 129:609-613

Efron B, Halloran E, Holmes S (1996) Bootstrap confidence levels for phylogenetic trees. Proc Natl Acad Sci USA 93:13429-13434

Felsenstein J (1978) Cases in which parsimony of compatibility methods will be positively misleading. Syst Zool 27:401-410

Hillis DM, Bull JJ (1993) An empirical-test of bootstrapping as a method for assessing confidence in phylogenetic analysis. Syst Biol 42:182-192

Kavinseksan B, Wongsiri S, De Guzman LI, Rinderer TE (2004) Absence of Tropilaelaps infestation from recent swarms of Apis dorsata in Thailand. J Apic Res 42:49-50

Koeniger N, Koeniger G, Delfinado-Baker M (1983) Observations on mites of the Asian honeybee species (Apis cerana, Apis dorsata, Apis florea). Apidologie 14:197-204

Koeniger G, Koeniger N, Anderson DL, Lekprayoon C, Tingek S (2002) Mites from debris and sealed brood cells of Apis dorsata colonies in Sabah (Borneo) Malaysia, including a new haplotype of Varroa jacobsoni. Apidologie 33:15-24

Krantz GW (1978) A manual of acarology. Oregon State University Bookstores, Corvallis

Kumar NR, Kumar R, Mbaya I, Mwangi RW (1993) Tropilaelaps clareae found on Apis mellifera in Africa. Bee World 74:101-102

Laigo FM, Morse RA (1968) The mite Tropilaelaps clareae in Apis dorsata colonies in the Philippines. Bee World 49:116-118

Lockhart PJ, Howe CJ, Bryant DA, Beanland TJ, Larkum AWD (1992) Substitutional bias confounds inference of cyanelle origins from sequence data. J Mol Evol 34:153-162

Lockhart PJ, Steel MA, Hendy MD, Penny D (1994) Recovering evolutionary trees under a more realistic model of sequence evolution. Mol Biol Evol 11: 605-612

Matheson A (1996) World bee health update 1996. Bee World 77:45-51

Navajas M, Fenton B (2000) The application of molecular markers in the study of diversity in acarology: a review. Exp Appl Acarol 24:751-774 
Navajas M, Gutierrez J, Bonato O, Bolland HR, Mapangou-Divassa S (1994) Intraspecific diversity of the cassava green mite Mononychellus progresivus (Acari: Tetranychidae) using comparisons of mitochondrial and nuclear ribosomal DNA sequences and cross-breeding. Exp Appl Acarol 18:351-360

Navajas M, Lagnel J, Gutierrez J, Boursot P (1998) Species-wide homogeneity of nuclear ribosomal ITS2 sequences in the spider mite Tetranychus urticae contrasts with extensive mitochondrial CO1 polymorphism. Heredity 80:742-752

Navajas M, Le Conte Y, Solignac M, Cros-Arteil S, Cornuet JM (2002) The complete sequence of the mitochondrial genome of the honeybee ectoparasite mite Varroa destructor (Acari: Mesostigmata). Mol Biol Evol 19:2313-2317

OIE (2004) Tropilaelaps infestation of honey bees (Tropilaelaps clareae, T. koenigerum). In: Manual of diagnostic tests and vaccines for terrestrial animals (mammals, birds and bees), chap 2.9.6, 5th edn. Office International des Epizooties, Paris

Otis GW (1996) Distributions of recently recognized species of honey bee (Hymenoptera: Apidae; Apis) in Asia. J Kan Entomol Soc 69:311-333

Otis GW, Kralj J (2001) Parasitic brood mites not present in North America. In: Webster TC, Delaplane KS (eds) Mites of the honey bee. Dadant and Sons, Illinois, pp 251-272

Posada D, Crandall KA (1998) MODELTEST: testing the model of DNA substitution. Bioinformatics 14:817-818

Ruttner F (1988) Biogeography and taxonomy of honeybees. Springer, Berlin

Saiki RK (1990) Amplification of genomic DNA. In: Innis MA, Gelfand DH, Sninsky JJ, White TJ (eds) PCR protocols. Academic Press, San Diego, pp 13-20

Sakagami ShF, Matsumura T, Ito K (1980) Apis laboriosa in Himalaya. The little known worlds largest honeybee (Hymenoptera, Apidae). Insecta Matsumurana 19:47-77

Sammataro D, Gerson U, Needham G (2000) Parasitic mites of honey bees: life history, implications and impact. Annu Rev Entomol 45:519-548

Simmons MP, Ochoterena H (2000) Gaps as characters in sequence-based phylogenetic analyses. Syst Biol 49:369-381

Simmons MP, Carr TG, O’Neill K (2004) Relative character-state space, amount of potential phylogenetic information, and heterogeneity of nucleotide and amino acid characters. Mol Phylogenet Evol 32:913-926

Smith DR, Villafuerte L, Otis G, Palmer MR (2000) Biogeography of Apis cerana F. and A. nigrocincta Smith: insights from mtDNA studies. Apidologie 31:265-279

Steel M (1994) Recovering a tree from the Markov leaf colourations it generates under a Markov model. Appl Math Lett 7:19-23

Swofford DL (1998) PAUP*: phylogenetic analysis using parsimony (* and other methods). Version 4.0d64. Sinauer Associates, Sunderland

Tangjingjai W, Verakalasa P, Sittipraneed S, Klinbunga S, Lekprayoon C (2003) Genetic differences between Tropilaelaps clareae and Tropilaelaps koenigerum in Thailand based on ITS and RAPD analyses. Apidologie 34:514-524

Tangkanasing P, Wongsiri S, Vongsamanode (1988) Integrated control of Varroa jacobsoni and Tropilaelaps clareae in bee hives in Thailand. In: Needham GR, Page RE Jr, Delfinado-Baker M, Bowan CE (eds) Africanised honey bees and bee mites. Halsted Press, New York, pp 409-412

Toda S, Osakabe MH, Komazaki S (2000) Interspecific diversity of mitochondrial CO-I sequences in Japanese Panonychus species (Acari: Tetranychidae). Exp Appl Acarol 24:821-829

Walter DE, Campbell NJH (2003) Exotic vs endemic biocontrol agents: would the real Stratiolaelaps miles (Berlese) Acari: Mesostigmata: Laelapidae), please stand up? Biol Control 26:253-269

White TJ, Bruns T, Lee S, Tayler J (1990) Amplification and direct sequencing of fungal ribosomal RNA genes for phylogenetics. In: Innis MA, Gelfand DH, Sninsky JJ, White TJ (eds) PCR protocols. Academic Press, San Diego, pp 315-322

Woyke J (1984) Survival and prophylactic control of Tropilaelaps clareae infesting Apis mellifera colonies in Afghanistan. Apidologie 15:421-434

Woyke J (1987) Length of successive stages in the development of the mite Tropilaelaps clareae in relation to honeybee brood age. J Apic Res 26:110-114

Woyke J (1994) Mating behaviour of the parasitic honeybee mite Tropilaelaps clareae. Exp Appl Acarol 18:723-733 